\title{
Reconstructing the landscape evolution and the human occupation of the Lower Sagone River (Western Corsica, France) from the Bronze Age to the Medieval period
}

\author{
Matthieu Ghilardi a,*, Daniel Istria ${ }^{\mathrm{b}}$, Andrés Curras ${ }^{\mathrm{a}, \mathrm{c}}$, Matteo Vacchi ${ }^{\mathrm{a}}$, Daniel Contreras ${ }^{\mathrm{d}, \mathrm{e}}$, Claude Vella ${ }^{\mathrm{a}}$, \\ Philippe Dussouillez ${ }^{\mathrm{a}}$, Yannick Crest ${ }^{\mathrm{d}, \mathrm{f}}$, Frédéric Guiter ${ }^{\mathrm{d}, \mathrm{e}}$, Doriane Delanghe ${ }^{\mathrm{a}}$ \\ a CEREGE UM 34 AMU CNRS UMR 7330, IRD, Collège de France, Aix-Marseille University, Europôle de l'Arbois BP 80, 13545 Aix-en-Provence CEDEX 04, France \\ b LA3M UMR 7298 CNRS, 5, rue du château de l'Horloge BP 647, 13094 Aix-en-Provence, France \\ c Fondation des Maisons des Sciences de l'Homme (FMSH), Paris, France \\ d Labex OT-MED, Aix-Marseille Université \\ e Institut Méditerranéen de Biodiversité et d'Ecologie marine et continentale (IMBE), AMU, CNRS, IRD, Avignon Université, Technopôle Arbois-Méditerranée, Bât. Villemin - BP 80, \\ F-13545 Aix-en-Provence Cedex 04, France \\ ${ }^{\mathrm{f}}$ HNHP UMR 7194 CNRS, University of Perpignan (UPVD), Perpignan, France
}

\section{A R T I C L E I N F O}

Article history:

Received 5 February 2016

Received in revised form 26 May 2016

Accepted 6 July 2016

Available online $\mathrm{xxxx}$

\begin{abstract}
A B S T R A C T
This paper aims to reconstruct the landscape evolution together with the vegetation history of the lower Sagone Valley, Western Corsica, which was occupied from the Bronze Age to the Medieval Period. Adopting a geoarchaeological approach, the combination of sedimentological, palynological, and geophysical data enables the reconstruction of various stages in the landscape evolution of the Lower Sagone River over the last 4000 years, together with the history of human occupation. The methods consist of a palaeoenvironmental study of 9 boreholes drilled in the modern deltaic plain, at a maximum distance of $500 \mathrm{~m}$ from the presentday shoreline. The laboratory analyses included mollusk identification and measurements of the grain-size distribution (by wet sieving). A series of 21 radiocarbon dates on charcoal, plant remains, wood fragments, and marine mollusk samples formed the basis for a chronostratigraphy. In order to reconstruct the vegetation history of the catchment, with particular attention to anthropogenic activity, pollen analysis was conducted on clay samples from the deepest borehole, and they revealed a semi-open forest during the Bronze Age and Late Iron Age with extensive pastoral activity and limited cereal cultivation. Electric Resistivity Tomography (ERT) of 3 profiles across the alluvial plain was conducted in order to reveal the geometry of the sedimentary bodies. The salient features are the presence of a freshwater lake during the Mid- to Late Bronze Age (from 1500 to $1100 \mathrm{cal}$. BC), its transformation into an open marine bay from ca. 1100 until $500 \mathrm{cal}$. BC, and the formation of a confined lagoon from 500 cal. BC to 200 cal. AD.
\end{abstract}

(c) 2016 Elsevier Ltd. All rights reserved.

\section{Introduction}

Corsica is the fourth largest Mediterranean island, covering an area of ca. $8631 \mathrm{~km}^{2}$, and is among the only ones in the Mediterranean to have permanent streams and a forested landscape on a large part of its territory. Despite the limited length of the main rivers (maximum length is ca. $90 \mathrm{~km}$ ), large alluvial coastal plains formed during the second half of the Holocene (Conchon, 1999); the largest deltas (Golo and Tavignano) are situated on the Eastern coast. As in other localities along the Mediterranean coastline, these fertile plains (which generally have been formed by extensive deposition of alluvial sediments) have been built by the combined effects of the slowing of the post-glacial sea-

\footnotetext{
* Corresponding author.

E-mail address: ghilardi@cerege.fr (M. Ghilardi).
}

level rise over the last six millennia (Vacchi et al., 2016) and the increase of sediment input caused by both natural and anthropogenic factors (Butzer, 2005; Anthony et al., 2014). However, the Holocene palaeoenvironmental dynamics and evolution of Corsican valleys have been little investigated. Only the Lower Taravo River has been the subject of an alluvial geoarchaeology study (Vella, 2010; Vella et al., 2014). In spite of this valuable pioneering work, the relationships between landscape evolution and human agricultural practices in the last four millennia in Corsica remain poorly understood, while on the coastal plains a large number of swamps/ponds have the potential to serve as palaeobotanical archives. In recent decades, numerous archaeological investigations in the lower river valleys on the western part of Corsica have highlighted an important human occupation from Mesolithic (Courtaud et al., 2014) to Medieval times (Istria, 2014a) and particular attention has been paid to the Neolithic, Bronze Age and Roman phases 
of colonization (Leandri and Istria, 2015) and human expansion, in particular within the lower river valleys. Some of these deeply incised valleys, such as Sagone, host a high concentration of figural menhirs, locally called Stantari. These statues with human-like faces, a symbol of prehistoric Corsica, were carved in granite and possibly date from the Bronze Age (3rd and 2nd millennia BC). One of the richest sites, known as Filitosa, is located within the Taravo River valley (Grosjean, 1961). Hypotheses regarding their origin and location include functions as road markers, crossroads, territorial boundaries, or landscape features such as wetlands. The Sagone Lower River Valley provides an interesting possibility to explain, or at least to better understand, the presence of the Late Bronze Age figural menhirs in relation with the landscape configuration by adopting a palaeoenvironmental approach based on sediment coring. Moreover, the assumption made by archaeologists about the potential existence of a harbor (or at least an anchorage) related to a wellattested roman villa during Roman times in the Sagone estuary led to the opportunity to reconstruct the shoreline displacements during the Late Holocene and to evaluate the influences of human occupation on the vegetation composition.

\section{Environmental setting and archaeological background}

\subsection{Geological, climatic and hydrological setting}

The Sagone River, located in SW Corsica (Fig. 1), is oriented NE/SW and is $\sim 18.2 \mathrm{~km}$ long; its drainage basin covers an area of ca. $79 \mathrm{~km}^{2}$. The maximum elevation in the upper reaches is $1273 \mathrm{~m}$ (Capu Sant'Anghjulu; Fig. 1) above mean sea level (amsl) and the mean slope is therefore ca. $5 \%$ (i.e., the slopes in the drainage are steep). The bedrock geology is characterized by Palaeozoic granites dated to 340-320 Ma (Carboniferous) on the western bank of the river, while sub-alkaline granites, dated from the Carboniferous/Permian ( 320 to $280 \mathrm{Ma}$ ), are found on the left bank (Rossi and Marre, 2010; Fig. 1).
The granites were deeply incised during the Messinian ( $5.3 \mathrm{Ma}) \mathrm{ma}-$ rine regression (the Proto-Mediterranean marine sea-level was ca. $1500 \mathrm{~m}$ below its present configuration; Clauzon, 1975) and later infilled with Pliocene, Pleistocene, and Holocene detrital material.

Geotechnical investigations conducted in 1974 by a private company revealed the stratigraphy of the Sagone coastal plain to a maximum depth of $25 \mathrm{~m}$ below the surface at a distance of 1 to $2 \mathrm{~km}$ inland from the present day shoreline (BRGM, 2012; Figs. 2A and B). The deepest borehole $(1135 \times 0109$, Figs. 2A and B; BRGM, 2012) clearly highlights three distinct sedimentary units: from ca 25 to $14 \mathrm{~m}$ below the surface, coarse deposits composed of pebbles, gravels and coarse sands indicate strong alluvial dynamics. The lowermost part of the unit is clearly related to an old terrace formation, probably dating from the Late Quaternary (Last Glacial Maximum?). Unfortunately, there is no radiometric dating of this basal coarse sedimentary unit, and a potential Pleistocene age of the old alluvial terrace can only be proposed. The second sedimentary unit is composed of finer deposits and occurs from ca. 14 to 5-6 $\mathrm{m}$ below the surface. The sediments are mainly composed of organic clays containing abundant plant remains and peat layers (Fig. 2B). Since bio-indicators were not studied, no clear facies identification is possible, and only limited interpretations can be made regarding the depositional environment (i.e., a calm environment such as a freshwater swamp or marsh). In addition, no radiocarbon dating was performed to date this sedimentary unit, which is recognized in different locations in the Lower Sagone River valley. It is obvious that this second sedimentary unit is of high palaeoenvironmental interest and new coring could help in reconstructing the palaeolandscape. The third, recently deposited, sedimentary unit recorded in all boreholes (Fig. 2B) is composed of heterogeneous material: fine sands, pebbles and organic clays. Again, the lack of dating or study of bio-indicators makes facies identification impossible without further work. While these limitations cannot be addressed directly, our sampling strategy in order to reconstruct the geomorphological changes within the Sagone plain was based on the

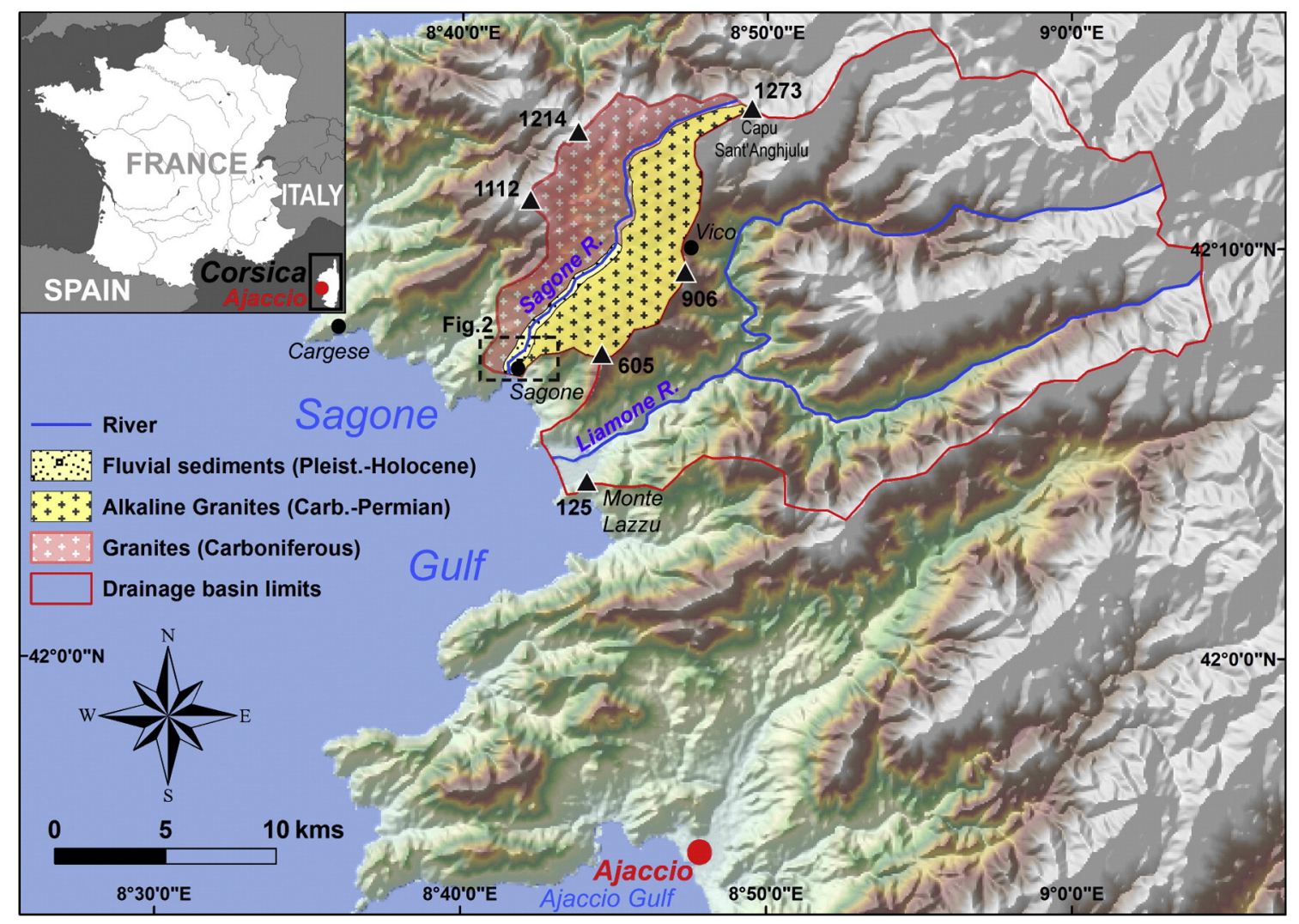

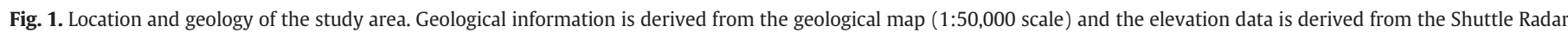
Topography Mission (version 3.0). 


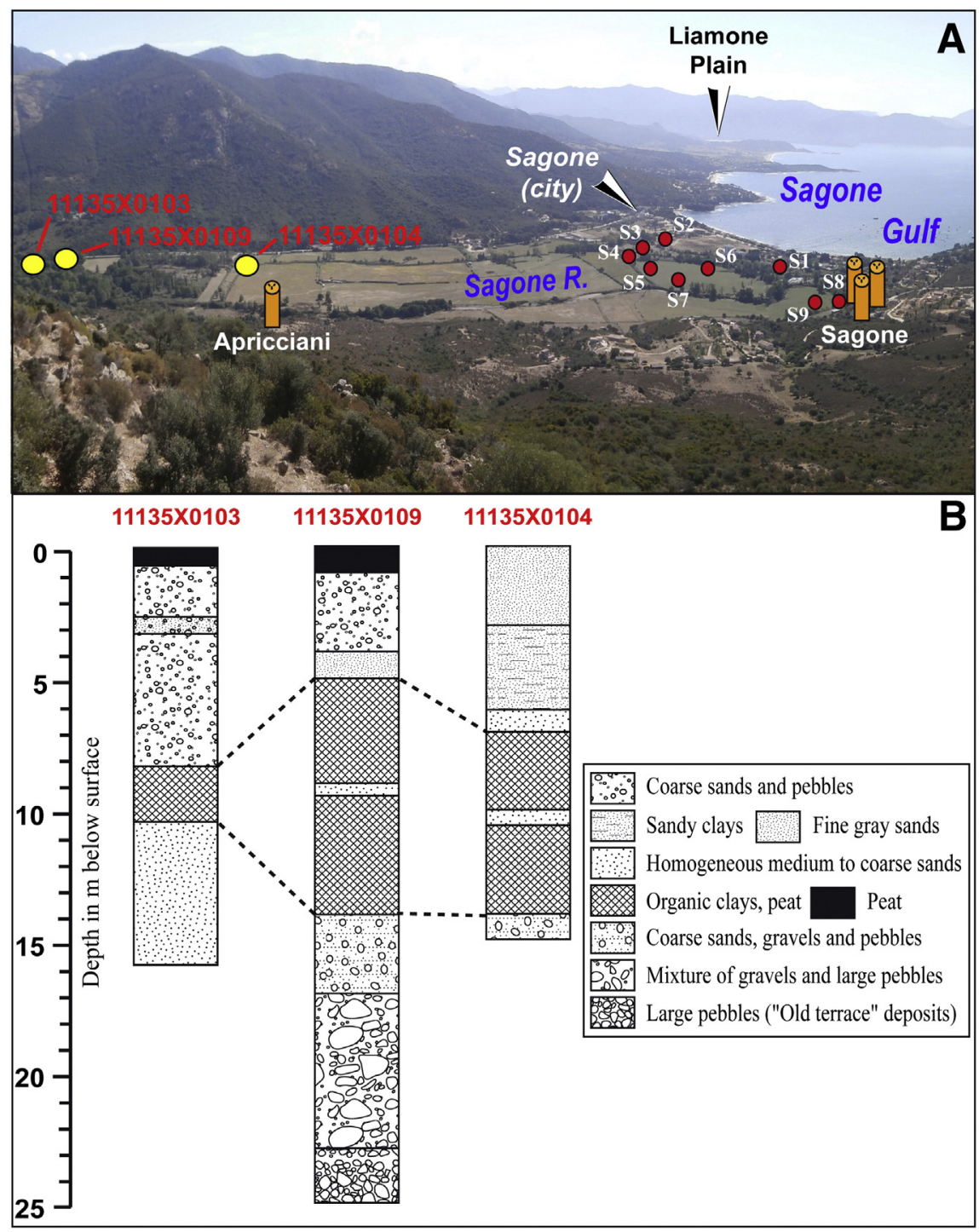

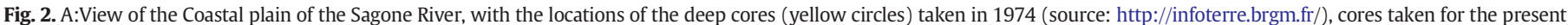

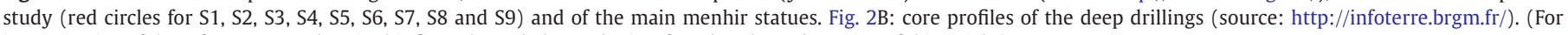
interpretation of the references to colour in this figure legend, the reader is referred to the web version of this article.)

information provided by the 1970s deep boreholes and is aimed at dating the different sedimentary units.

\subsection{Modern climate and vegetation}

From a climatic perspective, the Sagone catchment exhibits common features of the Mediterranean climatic zone: mean annual precipitation is $662 \mathrm{~mm}$, and annual average temperature is $15.4{ }^{\circ} \mathrm{C}$ (source: fr.climate-data.org/location/493159/). Significant dryness is observed during summer (from June to August) and major rainfall events are recorded during autumn (the peak is in November, with ca. $100 \mathrm{~mm}$ of precipitation; source: fr.climate-data.org/location/493159/).

The modern Sagone valley is characterized by strong human influences, including fires, which have perturbed the vegetation dynamics and shaped the landscape to a significant extent. Notwithstanding these features, the Sagone area is not substantially different from other western coastal sites of Corsica in terms of vegetation, climate, relief, or soils (Gamisans, 1999). Agricultural fields currently occupy the fluvial sedimentary deposits of the bottom valley of Sagone. Despite the present-day vegetation, this riverine environment is suitable for the development of forest comprising Alnus glutinosa, Salix cinerea and Vitis vinifera. The hills located on the eastern and western sides of the central lower plain rise around 200 and $400 \mathrm{~m}$ asl, which places them within the boundaries of the thermomediterranean and mesomediterranean vegetation in Corsica. Nevertheless, it is very common in areas such as Sagone, where the hills are very close to the sea, for the mesomediterranean lower belt to descend below its natural threshold and partially replace the littoral vegetation (Reille, 1984). In this area of Corsica the lower altitudinal stages close to the sea are characterized by the spread of mediterranean maquis comprising Pistacia lentiscus, Phyllirea latifolia, Fraxinus ornus and Euphorbia dendroides. On the steeper abrupt slopes and on rocky soils, communities of Juniperus phoenicia and Myrtus can be found. Quercus ilex, Arbutus unedo and Erica arborea occur near the sea, and they become more frequent with increasing altitude. Quercus suber may compete with Quercus ilex in these lower areas with mesophilous conditions. The degradation of the maquis forest can result in the spread of low-growing communities of Cistus monspeliensis and Cistus salviifolius shrubs, which can be particularly favored by fires.

\subsection{Human occupation of the Sagone catchment}

\subsubsection{Neolithic and bronze age periods}

Early traces of human occupation along the Sagone Gulf (lower Liamone River valley; Figs. 1 and 3) are dated to the Middle to Late 


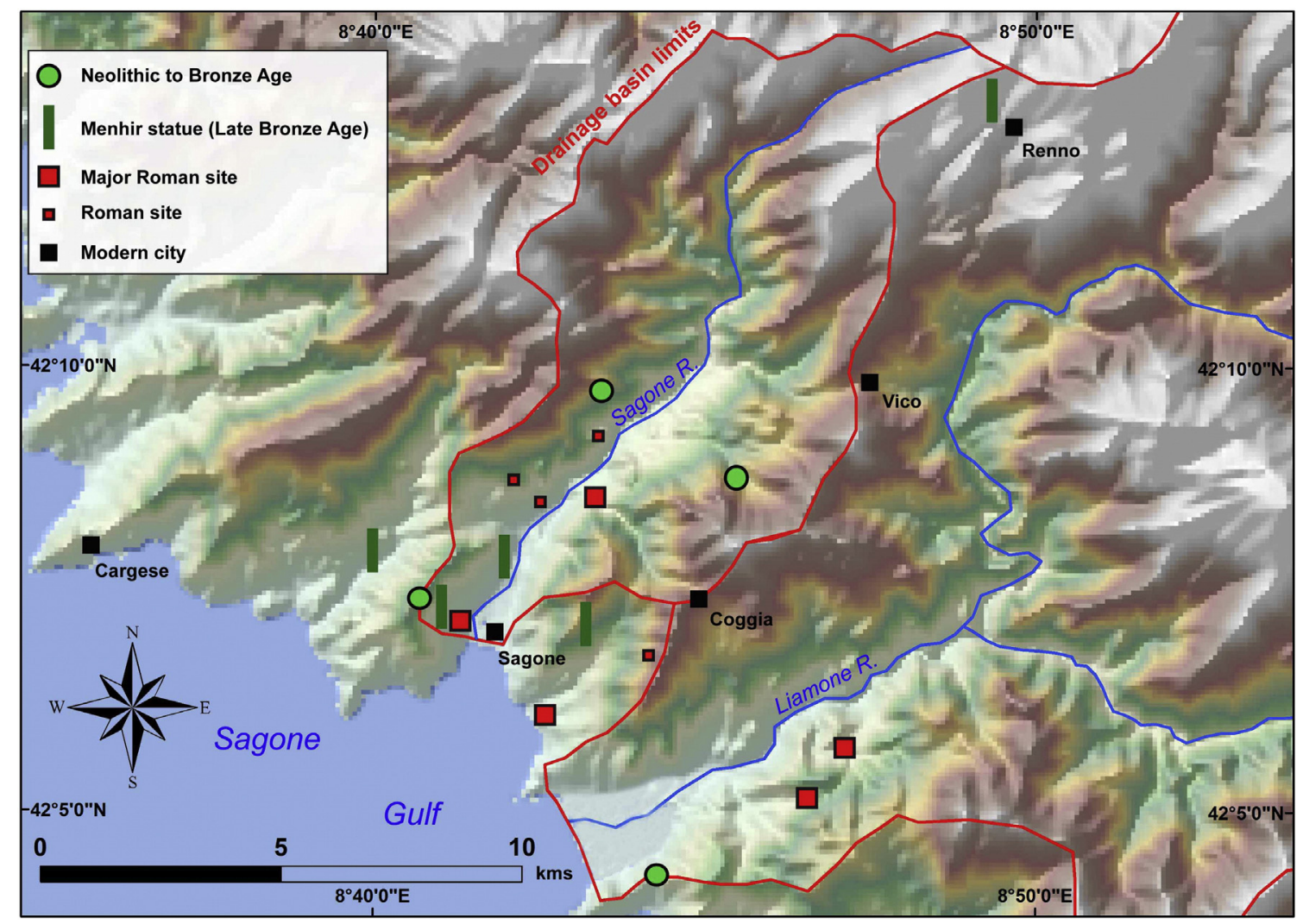

Fig. 3. Archaeological map of the Sagone drainage basin and its surroundings.

Neolithic period (ca. 4000 cal. BC) and consist of lithic artefacts and small depressions worn into the granite bedrock (Fig. 4A) that were used for crushing cereals (Weiss, 1984). These traces of ancient agricultural practices are found on a rocky promontory (locally named Monte Lazzu, Weiss, 1984) overhanging the Liamone Estuary, located $5 \mathrm{~km}$ south of the mouth of the Sagone river (Figs. 1 and 3). The Sagone River is generally called the "Valley of the figural menhirs" (Istria and Harnéquaux, 2010) since at least 3 to 4 large sculptured granite stones were discovered in both the upper drainage and the estuary. Unfortunately, most of them were probably moved from their primary location by locals during the medieval, modern, and contemporary periods (Istria and Harnéquaux, 2010).

The first and the most spectacular megalith is inside the remnant Cathedral of Sant'Appianu (Cesari et al., in press), built during the 12th Century AD on a rocky promontory and located on the right bank of the river (Fig. 4C1). In the foundations of the edifice, the menhir lies on edge and exhibits human features: the face, the neck and shoulders can be easily recognized (Cesari et al., in press). Its position clearly indicates the presence in the immediate vicinity of an old site, probably dated to the 3rd or 2nd millennium BC (Mid to Late Bronze Age). A second potential megalith is found within the southern wall of the Cathedral (Cesari et al., in press), but because of its similarity to the construction stones (i.e., rectangular pieces of granite) and its poor preservation, it cannot be conclusively identified as a sculptured stone (Fig. 4C2). The third sculptured granite stone is called the Man of Appriciani (l'Homme d'Appriciani) and was reported by the 19th Century traveler Prosper Mérimée (Mérimée, 1840) as being located only $1 \mathrm{~km}$ north of the Sant'Appianu Cathedral. Today, it is located close to the modern village of Vico (Fig. 4B), situated $10 \mathrm{~km}$ NE of Sagone. The fourth menhir statue, called the statue of Renno, was also reported by Merimee and was probably located in the upper part of the Valley, but has since been lost.

More megaliths can be found in the nearby valleys and uplands (Cesari and Leandri, 1994 and 2007), confirming the demographic expansion that occurred during the Mid- to Late Bronze Age in Corsica. However, the megaliths identified in the Sagone Valley do not exhibit weapons carved into the granite, such as the ones found in the Taravo Valley and in the Sartene Area (Istria and Harnéquaux, 2010). They show more similarities to the menhir statues found in Northern Corsica. The origin of the Corsican megaliths remains unclear; hypotheses regarding their location and significance suggest that may mark major roads or crossroads, territorial boundaries, or privileged places such as wetlands (Istria and Harnéquaux, 2010).

\subsubsection{Roman, early Christian, and medieval periods}

No evidence of Iron Age and Greek colonization of Corsica has yet been found in the Sagone Valley. Corsica remained under control of the Roman Empire from the 3rd Century BC until the 2nd Century AD (Istria et al., 2011) and in the Sagone Valley archaeologists have revealed traces of Roman Period occupation. The so called Volta Castle (Castellu di Volta), found in the upper part of the drainage basin, dates from the 3rd to 1st Century BC (Pêche-Quilichini, 2014). Ceramics and coins reveal that it was an important fortified site. In the lower river valley, a possible Roman villa has been recognized close to the 12th Century $\mathrm{AD}$ Sant'Appianu Cathedral, with the main buildings probably spanning $10,000 \mathrm{~m}^{2}$ (Istria, 2014b). Associated with the possible villa, archaeologists discovered baths, and have argued (Istria, 2014b) that a harbor was probably facilitating exchanges of agricultural goods across the Mediterranean, in particular with ancient colonies of the Roman Empire (the finds indicate that most of the trade was with modern Tunisia and NE Algeria). The existence of a coastal harbor located at the foot of the Sant'Appianu promontory was only suggested and could potentially highlight morphological changes of the Sagone estuary since the last millennia. Following Roman times, there is evidence of an early Christian site and the later construction of the Sant'Appianu Cathedral during the 12th Century AD (Istria, 2009 and 2014b; Istria et al., 2012). 

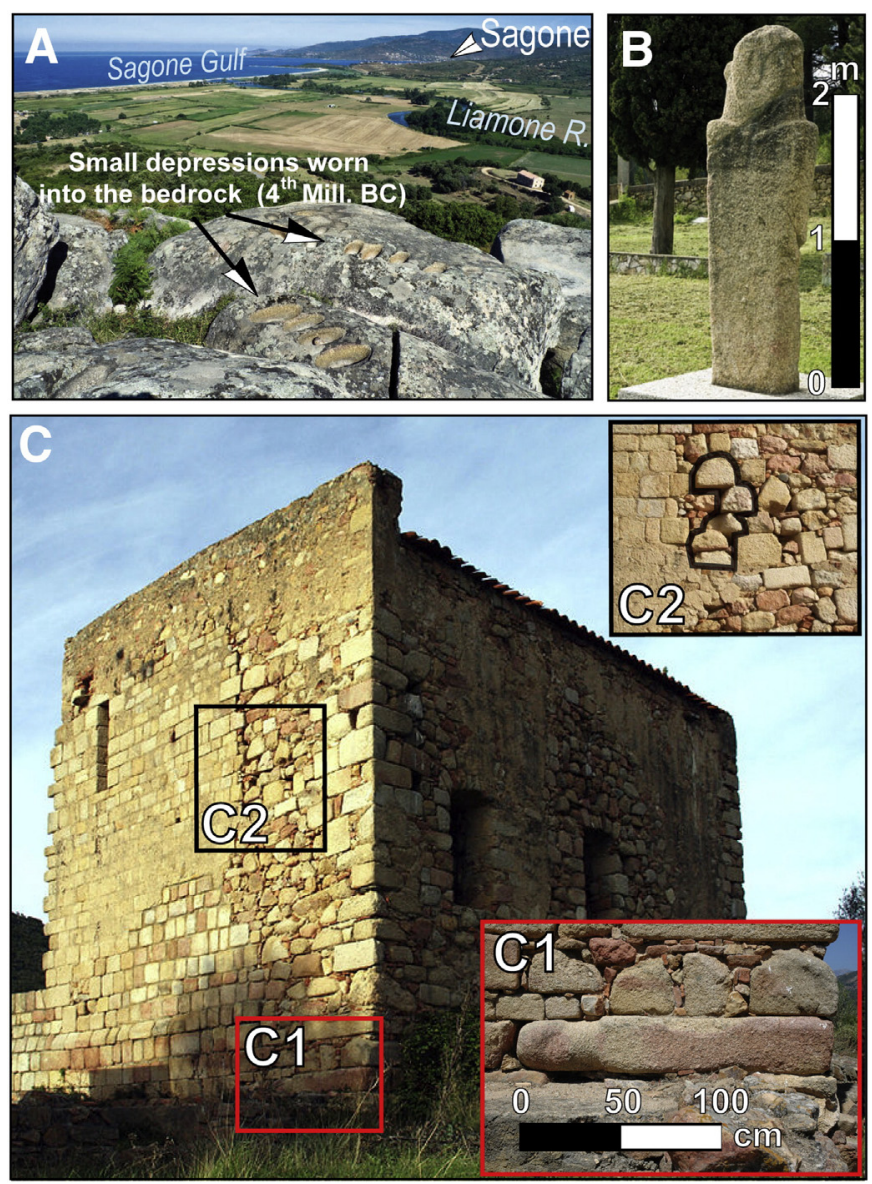

Fig. 4. Archaeological evidence for the occupation of the Sagone catchment and its surroundings. Fig. 3A: Picture of the Monte Lazzu (Liamone catchment), bedrock mortars for cereal processing (4th Millennium BC). Fig. 3B: Menhir Statue of Apricciani (Lower Sagone River valley), see Fig. 2A for location. Fig. 3C: Sant'Appianu cathedral (12th Cent. AD) with reuse of menhir satues ( $C 1$ and $\mathrm{C} 2$ ) as foundation stones.

\section{Methods}

In order to reconstruct the Sagone palaeoenvironments, nine 50$\mathrm{mm}$ diameter vibracores were drilled in May and September 2013 in the Sagone coastal plain, reaching a maximum depth of $6.30 \mathrm{~m}$ below the surface (Table 1, Figs. 2A and 5). Each borehole was located and its surface elevation determined with a Trimble R8 dGPS connected to the national RGP (Réseau GNSS permanent) network from IGN (Institut Géographique national); consequently, the vertical error is very small: $\pm 1 \mathrm{~cm}$ (Table 1 ). Laboratory analyses were undertaken at CEREGE in Aix-en-Provence (France). Sampling was performed every $5 \mathrm{~cm}$ for mollusk identification, pollen, non-pollen palynomorphs, and sedimentological analysis.

\subsection{Mollusk and wood identifications/AMS dating}

All samples were wet-sieved through a wire screen $(0.40 \mathrm{~mm}$ mesh) and air dried at room temperature. The residue was examined under a binocular microscope and all identifiable shells and characteristic shell, plant, and charcoal fragments were recovered and curated in separate plastic tubes. The chronostratigraphy of the cores was established by a series of 21 AMS radiocarbon dates taken from plant remains, wood fragments organic matter samples, and marine shells (Table 2). The dating analyses were performed at the Poznan Laboratory for Radiocarbon (Poland). Subsequently, the marine sample was corrected for the marine reservoir effect according to Siani et al. (2000) and Reimer and McCormac (2002), where $\Delta R=46 \pm 40$, although it must be emphasized that the real (palaeo) reservoir effect varies widely in different marine environments such as lagoons, coastal swamps or littoral zones (Vött, 2007). ${ }^{14} \mathrm{C}$ ages were subsequently calibrated using the IntCal13 and Marine13 curves (Reimer et al., 2013) and Calib 7.0.1 software.

\subsection{Grain-size analyses}

Samples were taken at 5-cm intervals. Many contained coarse particles (gravels to pebbles), above $2 \mathrm{~mm}$, and wet-sieving by hand was then used to isolate the total fractions of coarse $(>2 \mathrm{~mm})$ and fine sediments $(<2 \mathrm{~mm})$. Granulometry has been widely used in sedimentological studies conducted in deltaic contexts (Ghilardi et al., 2014) and used to reconstruct the energy of the depositional environment.

\subsection{Pollen analyses}

Pollen samples were treated following standard preparation procedures according to Fægri and Iversen (1989). Pollen and non-pollen palynomorphs (NPP) were counted and identified at $\times 400$ magnification by reference to published illustrations and morphological keys (Reille, 1992, 1995, and Reille, 1998a; van Geel, 2001). Determination of Cerealia pollen was carried out according Andersen (1979). A stratigraphical representation of several pollen and non-pollenpalynomorph taxa was achieved by plotting taxa against the ages provided by the chronostratigraphy for core Sagone 7. In total, twelve sedimentary samples provided a minimum of 300 pollen grains so that a statistically reliable palaeoecological analysis was possible. These samples are from the depths of 2.20, 2.42, 5.03, 5.10, 5.17, 5.25, 5.70, 5.85, $5.95,6.05,6.18$ and $6.25 \mathrm{~m}$. Subsequently, the percentages were calculated on the basis of the sum of total land pollen, excluding those of undetermined, aquatic taxa, hygrophilous taxa, and NPP.

\subsection{Geophysical survey: Electric resistivity tomography (ERT)}

The geometry and location of the main sub-surface structures were analysed using electrical resistivity tomography (ERT). This method differs from the conventional DC resistivity survey in using a large array of electrodes and by recording the maximum of independent measurements that are possible on the array (Griffiths et al., 1990). A

Table 1

Borehole information: *borehole drilled in May 2013 and **borehole drilled in September 2013.

\begin{tabular}{|c|c|c|c|c|}
\hline Borehole reference & Latitude (WGS 84, decimal degrees) & Longitude (WGS 84, decimal degrees) & Elevation (in m) & Depth (in m) \\
\hline Sagone $1(\mathrm{~S} 1)^{*}$ & N42.116684 & E8.693794 & +1.19 & 1.1 \\
\hline Sagone $2(\mathrm{~S} 2)^{*}$ & N42.116492 & E8.697866 & +1.21 & 4 \\
\hline Sagone $3(\mathrm{~S} 3)^{*}$ & N42.117773 & E8.697993 & +1.34 & 4.1 \\
\hline Sagone $4(\mathrm{~S} 4)^{*}$ & N42.118487 & E8.697383 & +1.40 & 4.2 \\
\hline Sagone $5(\mathrm{~S} 5)^{*}$ & N42.119059 & E8.696196 & +1.55 & 4.2 \\
\hline Sagone $6(\mathrm{~S} 6)^{* *}$ & N42.118151 & E8.694903 & +0.93 & 3.9 \\
\hline Sagone $7(\mathrm{~S} 7)^{* *}$ & N42.119396 & E8.694808 & +1.61 & 6.3 \\
\hline Sagone $8(\mathrm{~S} 8)^{* *}$ & N42.118734 & E8.690571 & +1.10 & 3.15 \\
\hline Sagone 9 (S9) ${ }^{* *}$ & N42.11902 & E8.691019 & +1.21 & 4.2 \\
\hline
\end{tabular}




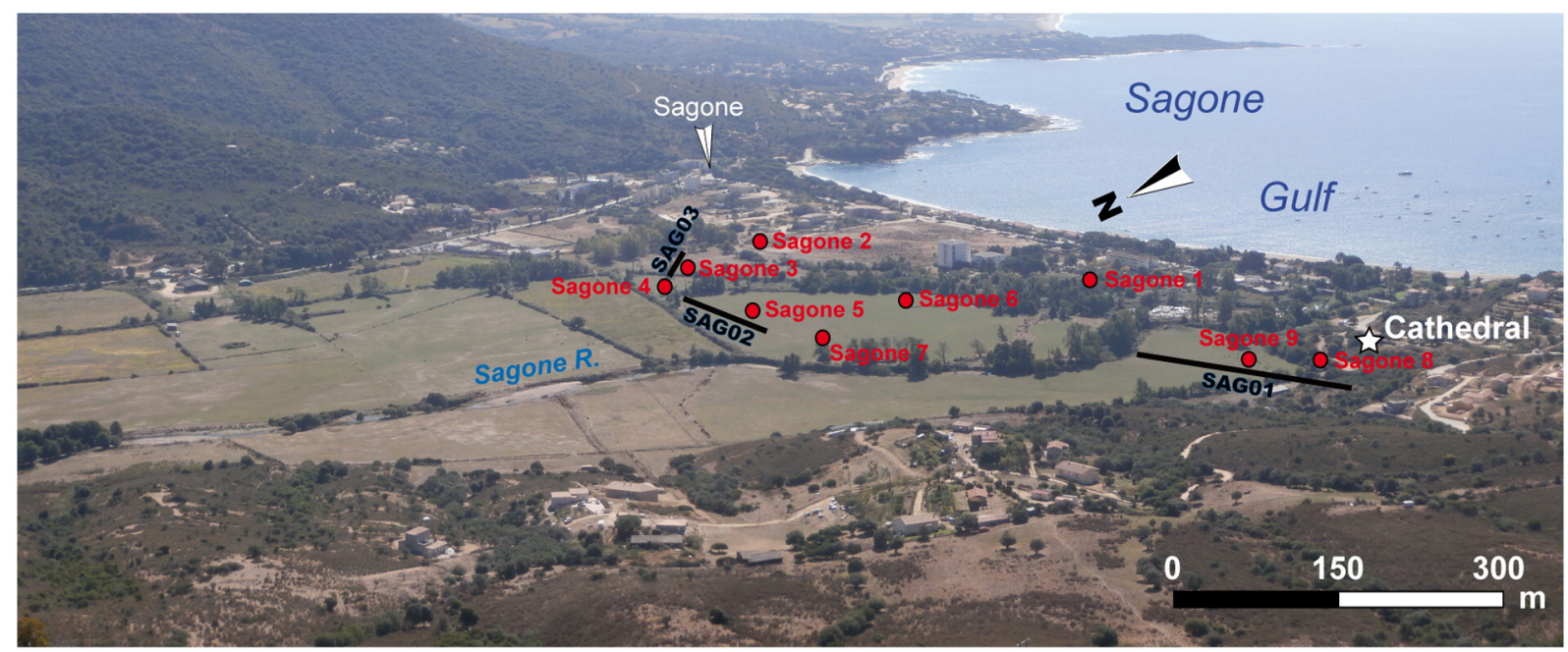

Fig. 5. Oblique view of the Sagone coastal/deltaic plain with location of the boreholes drilled (red circles) and the ERT profiles (black lines) established for the present study.

computer-inversion programme (Res2Dinv, Loke, 2003) including the topography generates images of resistivity distribution on a cross section below the survey line. ERT has been successfully used in various sub-surface field surveys, particularly in geomorphology (Van Dam, 2012; Beauvais et al., 2007) and archaeology (Siart et al., 2010; Quesnel et al., 2011, Vella, et al., 2013; Ghilardi et al., 2015). In the present study, 2D-resistivity tomography was obtained by employing the ABEM Lund Imaging System (SAS4000 + ES1064) with an array of 64 electrodes using a Schlumberger-Wenner reciprocal layout protocol. The unit electrode spacing affects the length of the profile, exploration depth, and resolution (Ritz et al., 1999; Beauvais et al., 2004). Wide electrode spacing is used to investigate deep and large structures, while close electrode spacing allows detection of small structures but with a shallower maximum depth of investigation. Within the Sagone coastal plain, electrode spacings of $1 \mathrm{~m}, 2 \mathrm{~m}$ and $2.5 \mathrm{~m}$ allowed investigation depths of ca. 8, $16 \mathrm{~m}$ and $20 \mathrm{~m}$, respectively, representing a satisfactory compromise for providing information about the thickness of the superficial material and its structure. The ERT method, however, does not provide a unique interpretation, since different materials can have similar electrical properties. Consequently, interpretation depends on a detailed knowledge of the local context and, where possible, needs to be validated by drilling.

\section{Results}

\subsection{General stratigraphy and definition of sedimentary environments}

Based on the sedimentological analyses and mollusk identification, various sedimentary units can be distinguished (Figs. 6, 7 and 8), as follows:
- Unit A is only found in the basal part of core Sagone 7 (Fig. 7) and consists of organic black clays with occasional intercalations of peat and wood remains, mainly in the lowermost part. The thickness is about $1.20 \mathrm{~m}$ and it is noteworthy that towards the upper part, thin layers (maximum $3 \mathrm{~cm}$ ) of coarse gray sands containing marine shell fragments (Bittium reticulatum and unidentified bivalve) are intercalated with the organic black clays. A radiocarbon date on plant remains from the deepest part of the unit gave an age of 1611-1447 cal. BC, while an age of 1497-1309 cal. BC (Table 2) is re- corded in the mid part of the unit, and finally the uppermost part (transition with Unit B) is dated from 1207-1004 cal. BC. Pollen is abundant and well preserved (see Section 4.2.), and reveals the exis- tence of a freshwater environment (pond or a shallow lake) with calm deposition.

Table 2

Radiocarbon dating results (see the methods section for more information.)

\begin{tabular}{|c|c|c|c|c|c|c|c|c|}
\hline Core reference & Sample reference & $\begin{array}{l}\text { Depth } \\
\text { (in } \mathrm{m})\end{array}$ & $\begin{array}{l}\text { Absolute elevation } \\
\text { (in } \mathrm{m} \text { amsl) }\end{array}$ & Material & $\mathrm{BP}$ & Error \pm & cal. $2 \sigma$ & Laboratory reference \\
\hline Sagone 2 & Sagone 2_C4-3.89 & 3,89 & -2.68 & Wood & 2915 & 30 & 1209-1016 BCE & Poz-58644 \\
\hline Sagone 4 & Sagone 4_C4 4.17 & 4,17 & -2.77 & Marine shell (Bittium reticulatum) & 3930 & 35 & 2059-1734 BCE & Poz-56333 \\
\hline Sagone 5 & Sagone 5_C2-2.03 & 2,03 & -0.48 & Wood & 945 & 25 & $1028-1154$ CE & Poz-58642 \\
\hline Sagone 5 & Sagone 5_C3-3.15 & 3,15 & -1.6 & Wood (Quercus ilex) & 1125 & 25 & 869-989 CE & Poz-55976 \\
\hline Sagone 6 & Sagone 6_C2 1.32 & 1,32 & -0.39 & Plant remains & 780 & 30 & $1210-1280 \mathrm{CE}$ & Poz-65996 \\
\hline Sagone 6 & Sagone 6_C2 2.00 & 2 & -1.07 & Organic sediment + plant remains & 2175 & 30 & $361-163$ BCE & Poz-65925 \\
\hline Sagone 7 & Sagone 7_C3 2.28 & 2,28 & -0.67 & Organic sediment & 2175 & 30 & 361-163 BCE & Poz-65991 \\
\hline Sagone 7 & Sagone 7_C3 2.40 & 2,4 & -0.79 & Plant remains & 2290 & 30 & $405-231 \mathrm{BCE}$ & Poz-65992 \\
\hline Sagone 7 & Sagone 7_C3 2.45 & 2,45 & -0.84 & Plant remains & 2360 & 30 & $536-383 \mathrm{BCE}$ & Poz-65994 \\
\hline Sagone 7 & Sagone 7_C3 2.80 & 2,82 & -1.21 & Plant remains & 2245 & 30 & 393-206 BCE & Poz-65995 \\
\hline Sagone 7 & Sagone 7_C5 4.72 & 4,72 & -3.11 & Posidonia oceanica & 2945 & 30 & $818-544$ BCE & Poz-61972 \\
\hline Sagone 7 & Sagone 7_C5 4.89 & 4,89 & -3.28 & Wood & 2900 & 30 & $1207-1004$ BCE & Poz-61969 \\
\hline Sagone 7 & Sagone 7_C6 5.93 & 5,93 & -4.32 & Organic sediment & 3145 & 30 & 1497-1309 BCE & Poz-61971 \\
\hline Sagone 7 & Sagone 7_C6 6.30 & 6,3 & -4.69 & Plant remains & 3245 & 30 & 1611-1447 BCE & Poz-61968 \\
\hline Sagone 8 & Sagone 8_C2 1.35 & 1,35 & -0.25 & Organic sediment + plant remains & 20 & 60 & $1681-1938 \mathrm{CE}$ & Poz-65998 \\
\hline Sagone 8 & Sagone 8_C2 1.55 & 1,55 & -0.45 & Peat & 2300 & 35 & $411-211$ BCE & Poz-65999 \\
\hline Sagone 8 & Sagone $8 \_C 21.70$ & 1,7 & -0.6 & Organic sediment & 2570 & 30 & 809-559 BCE & Poz-66000 \\
\hline Sagone 9 & Sagone 9_C2 1,36 & 1,36 & -0.15 & Plant remains & 730 & 30 & 1224-1297 CE & Poz-58646 \\
\hline Sagone 9 & Sagone 9_C2 1,53 & 1,53 & -0.32 & Plant remains & 1105 & 25 & 889-991 CE & Poz-58647 \\
\hline Sagone 9 & Sagone 9_C2 1,67 & 1,67 & -0.46 & Plant remains & 1400 & 30 & $599-668 \mathrm{CE}$ & Poz-58648 \\
\hline Sagone 9 & Sagone 9_C2 1,80 & 1,8 & -0.59 & Plant remains & 1940 & 40 & $0-129 \mathrm{CE}$ & Poz-58650 \\
\hline
\end{tabular}




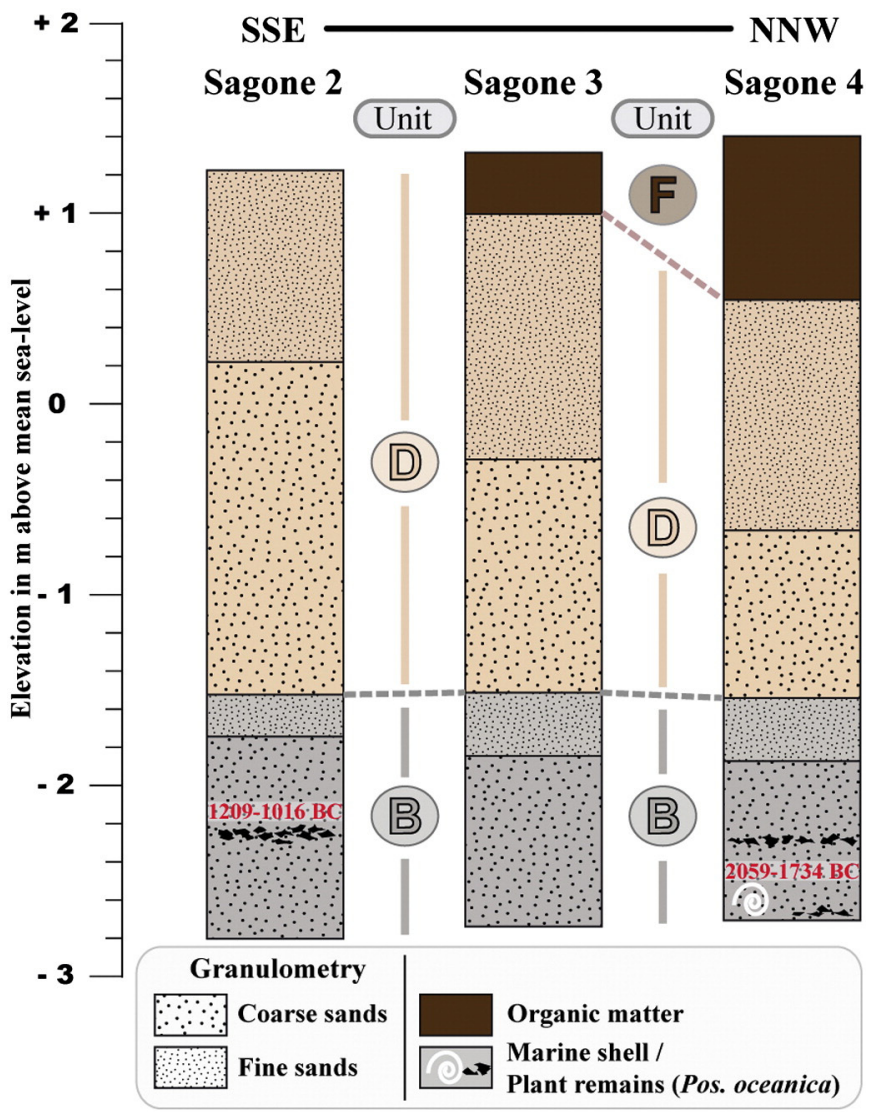

Fig. 6. Core profiles of Sagone 2, 3 and 4 boreholes.

- The second unit (Unit B) is found in all cores (Figs. 6, 7 and 8) except Sagone 5. It consists of homogenous medium to coarse gray sands; where marine gastropods are identified, Bittium reticulatum is the dominant species. The mollusks are generally poorly preserved and numerous shell fragments (impossible to identify due to their small size) were encountered, while the only intact mollusks are generally cone shaped, such as Bittium reticulatum. One of these was dated in Sagone 4 (Fig. 6) and gave an age of 2059-1734 cal. BC. Layers of the marine plant Posidonia oceanica also occur in Unit B and are dated to 814-544 cal. BC in Sagone 7 (Fig. 7), while in the uppermost part of Sagone 8 (Fig. 7), they are mixed with organic sediment and dated to $809-559 \mathrm{cal}$. BC and $411-211 \mathrm{cal}$. BC. Unit B is characteristic of a marine environment with high energy of deposition.

- The third sedimentary unit (C) is found in cores Sagone 6, 7, 8 and 9 (Figs. 7 and 8), and was not recognized in cores Sagone 1, 2, 3, 4, and 5. It overlies Unit B and consists of dark organic clays containing few bio-indicators. Small bivalve fragments (Cerastoderma glaucum) are occasionally present but their very small size $(<1 \mathrm{~mm})$ suggests that they were probably not deposited in situ. Ostracods were also studied under a binocular microscope and only the lagoonal species Cyprideis torosa was found; however, its very sparse occurrence may suggest a lagoonal environment altered due to significant freshwater influx or a limited connection with the sea. The grain size decreases gradually from the top of Unit B (coarse to fine sands) to Unit C which consists mainly of clays rich in organic matter. The sediments of Unit $C$ were deposited under calm conditions where connections with the sea existed but were rather restricted. The thickness of the brackish unit $C$ does not exceed $30 \mathrm{~cm}$ in Sagone 7, while it is $20 \mathrm{~cm}$ in Sagone 6 and only $5 \mathrm{~cm}$ in Sagone 8 and 9. It is interesting that the brackish environments were mainly developed in the central west part of the Sagone coastal plain, in the vicinity of cores
Sagone 6 and 7 (Fig. 7). Radiocarbon dating of the transition from marine Unit B to Unit C gave an age ranging from 536-383 cal. BC in Sagone 7 (central west part of the plain) to $0-129$ cal. AD in Sagone 9 (western part of the plain and situated at the foot of the Sant'Appianu Cathedral). All of the foregoing results indicate that lagoonal conditions prevailed in the area from the 6th Century BC until the 2nd Century AD.

- Sedimentary Unit D is only found in Sagone 2, 3, 4 and 5 (Figs. 6 and $8)$. It consists of light pink to gray coarse sands with a thickness ranging from $3 \mathrm{~m}$ (Sagone 2) to $2.5 \mathrm{~m}$ (Sagone 3), to $2 \mathrm{~m}$ (Sagone 4), to only $35 \mathrm{~cm}$ in Sagone 5. These sands do not exhibit any bedding and do not contain organic matter, thus limiting the identification of the environment of deposition. However, an environment which is the equivalent of Unit D occurs today in the central part of the Sagone coastal plain and comprises the modern sand dunes. The sediments from Unit D directly overlie marine Unit B in cores Sagone 2, 3 and 4 (Fig. 6), while in core Sagone 5 they are situated above the fluvial sands and organic clays from the abandoned channel dated to the 11th/12th Century AD (Fig. 7). Radiocarbon dating of the basal part of Unit D is difficult for Sagone 2, 3 and 4 (Fig. 6) since there is minimal organic matter content and its age can only be inferred from the dating of the uppermost part of marine Unit B. In Sagone 2, 3 and 4, an approximate age of ca. $1000 \mathrm{cal}$. BC can be proposed on the basis of dating of the uppermost part of Unit B in core Sagone 2 (Fig. 6).

- Unit E can only be recognized in cores Sagone 5, 6 and 7 (Figs. 7 and 8). The sediment composition is heterogeneous in Sagone 5. In the lower and central parts of the unit there are mainly gravels to small rounded pebbles of granite, while towards the top of the unit there are fine to medium yellow to gray sands. The thickness is about $1 \mathrm{~m}$ and the basal part is dated to 869-989 cal. AD (wood fragment, Quercus ilex) in core Sagone 5 (Fig. 8). Above this coarsegrained unit, a sub-unit consisting of clays containing numerous plant remains and wood fragments is dated in its lowermost part to $1028-1154 \mathrm{cal}$. AD (wood fragment from the transition with the coarse sediments). In Sagone 5, Unit E can be associated with fluvial deposits and abandoned channel sediments and corresponds to a palaeochannel of the Sagone River dated to the 9th to 12th Century AD. In Sagone 6 and 7, this unit is composed of fine material, generally ranging from fine to medium yellow sands. The thickness is about $30 \mathrm{~cm}$ in Sagone 6, where fluvial deposits of low energy are found above the brackish Unit C. In Sagone 7, Unit E is $0.80 \mathrm{~m}$ thick and is composed in its lowermost part of medium to coarse yellow sands (from 0.50 to 0.80 m below surface) and of silty clays from the surface to $0.50 \mathrm{~m}$ deep. Its age is uncertain but it probably post-dates the Little Ice Age.

- Unit $\mathrm{F}$ is found in all cores except Sagone 1,2 and 7. It is composed of dark (black) organic clays and its thickness generally increases from east to west. It is found in the upper part of cores Sagone 3 (from the surface to $0.35 \mathrm{~m}$ deep) and Sagone 4 (from the surface to $0.90 \mathrm{~m}$ deep) where it overlies sand dune deposits. Radiocarbon dates have not been obtained, but the age must be recent (i.e., Little Ice Age or later). In Sagone 6, where Unit F is found from the surface to $1.50 \mathrm{~m}$ deep, plant remains from the lowermost part of the unit are dated to $1210-1280 \mathrm{cal}$. AD.

\subsection{Pollen stratigraphy}

The samples located between 5.25 and 6.25 m depth (Fig. 9) all exhibit high frequencies of arboreal pollen, with a noticeable dominance of Alnus glutinosa. In the group of samples located at 5.70, 5.85, 5.95, $6.05,6.18$ and $6.25 \mathrm{~m}$ depth, Alnus glutinosa attains values between 40\% and 60\%. Quercus (between 15 and 20\%) and Pinus (usually below 5\%) are also reported. Erica arborea is the best represented among the 


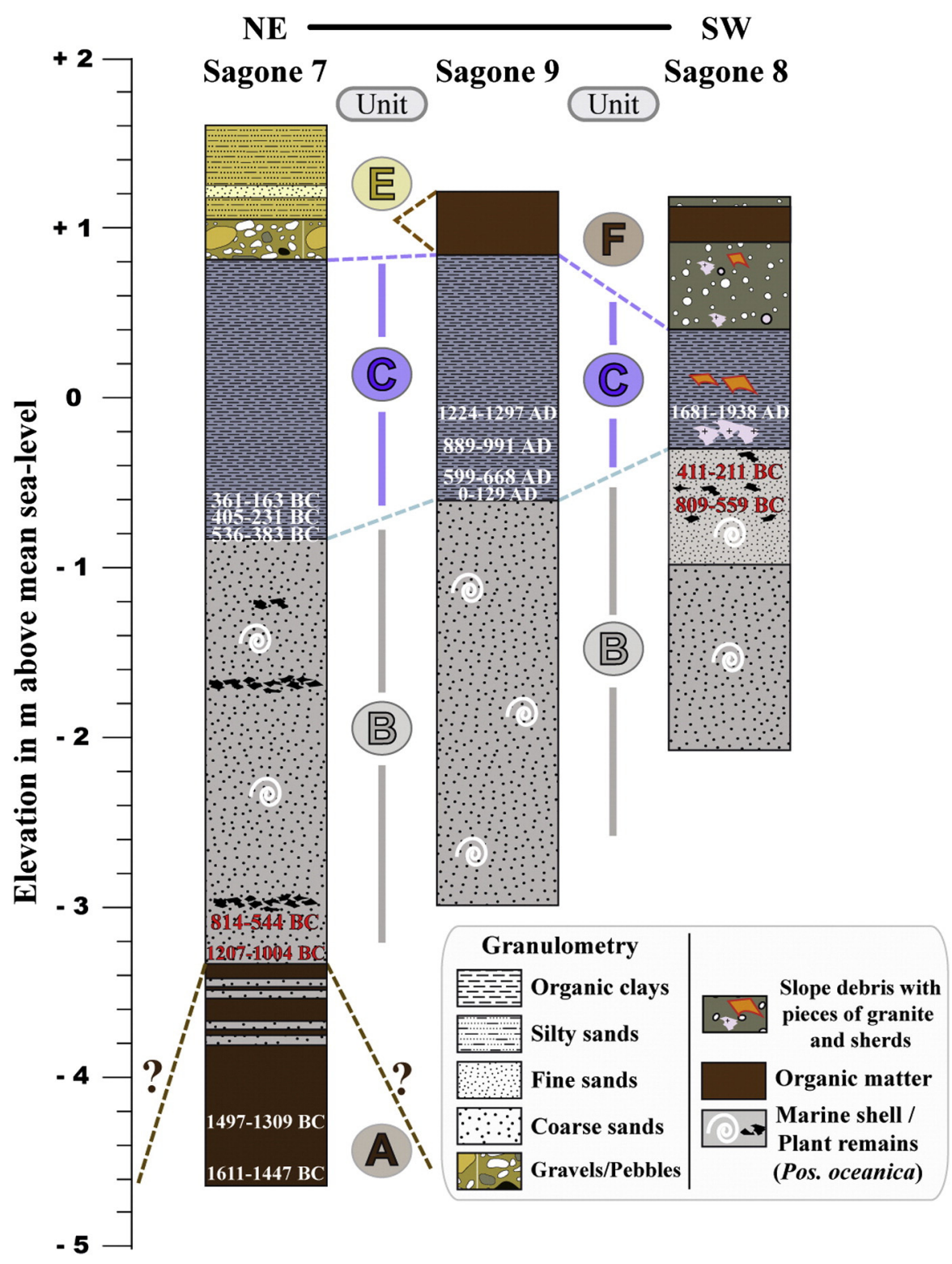

Fig. 7. Core profiles of Sagone 7, 8 and 9 boreholes.

shrub taxa, and exhibits a decreasing trend from $14 \%$ in the lower samples to $<10 \%$ at $5.70 \mathrm{~m}$ depth. Pistacia (corresponding entirely to P. lentiscus in Corsica), Fraxinus, and Myrtus are also represented, usually with values of $<4 \%$. Vitis is also recorded along these samples. Although the cultivated species of Vitis cannot reliably be differentiated from the wild ones on the basis of pollen morphology alone, the relatively high values of Vitis in some of the samples (3.6\% at $6.05 \mathrm{~m}$ depth) suggest a wild origin (riparian environments), as Vitis cultivation on such a large scale is unlikely. Among the herbaceous taxa, Poaceae dominates with values close to $5 \%$. There is the minor representation of ruderal and anthropogenic-related taxa such as Cichorioideae, Asteroideae and Rumex, Plantago lanceolata-type and Trifolium-type between 5.70 and $6.25 \mathrm{~m}$ depth. It is noteworthy that the sample from $6.18 \mathrm{~m}$ depth records the highest values of Cichorioideae (3.4\%) and Poaceae (5.1\%). There is evidence of cultivated cereal pollen in samples from 5.85, 5.95, 6.05 and $6.25 \mathrm{~m}$ depth. Aquatic and hygrophilous taxa occur at $6.25 \mathrm{~m}$ depth, but their representation increases from $6.05 \mathrm{~m}$ depth, as evidenced by the occurrence of Cyperaceae pollen. With regard to NPP taxa, dung-related spores such as Sporormiella, Sordaria and Delitschia occur within this lower group of samples. The values of coprophilous Sporormiella spores increase between $6.18 \mathrm{~cm}$ and $5.85 \mathrm{~m}$ depth.
The pollen samples located between 5.05 and 5.25 m depth (Fig. 9) exhibit evidence similar percentages to the lower samples. Alnus glutinosa pollen (ca. 40\%) still dominates among the forest taxa, while Quercus exhibits slightly higher values (ca. 20\%). The same shrub taxa are evident in this group of samples. Erica values remain unchanged except for the peak of $21 \%$ at $5.10 \mathrm{~m}$ depth. Poaceae dominates among the non-arboreal taxa, and exhibits an increasing trend towards $5.05 \mathrm{~m}$ depth. Ruderal and anthropogenic taxa are present but not in significant percentages, similar to the lower samples. However, there is no evidence of cereal or any other crop plants. Among the herbaceous taxa, the only differences are in Apiaceae, which records higher values, while Brassicaceae decreases. Dung-related spores of Sporormiella are present in minor quantities through these samples, although its representation, together with other coprophilous taxa such as Sordaria, is continuous.

The uppermost samples, at 2.20 and $2.42 \mathrm{~m}$ depth (Fig. 9), exhibit low frequencies of the forest taxa, indicated by the reduced percentages of Alnus glutinosa (below 30\%) and Quercus (13\%), while Erica is roughly constant and Pinus records slightly higher values. The shrub taxa found in the lower samples are still apparent but in lower abundance, and some of them disappear, such as Pistacea and Tamarix. In contrast to 


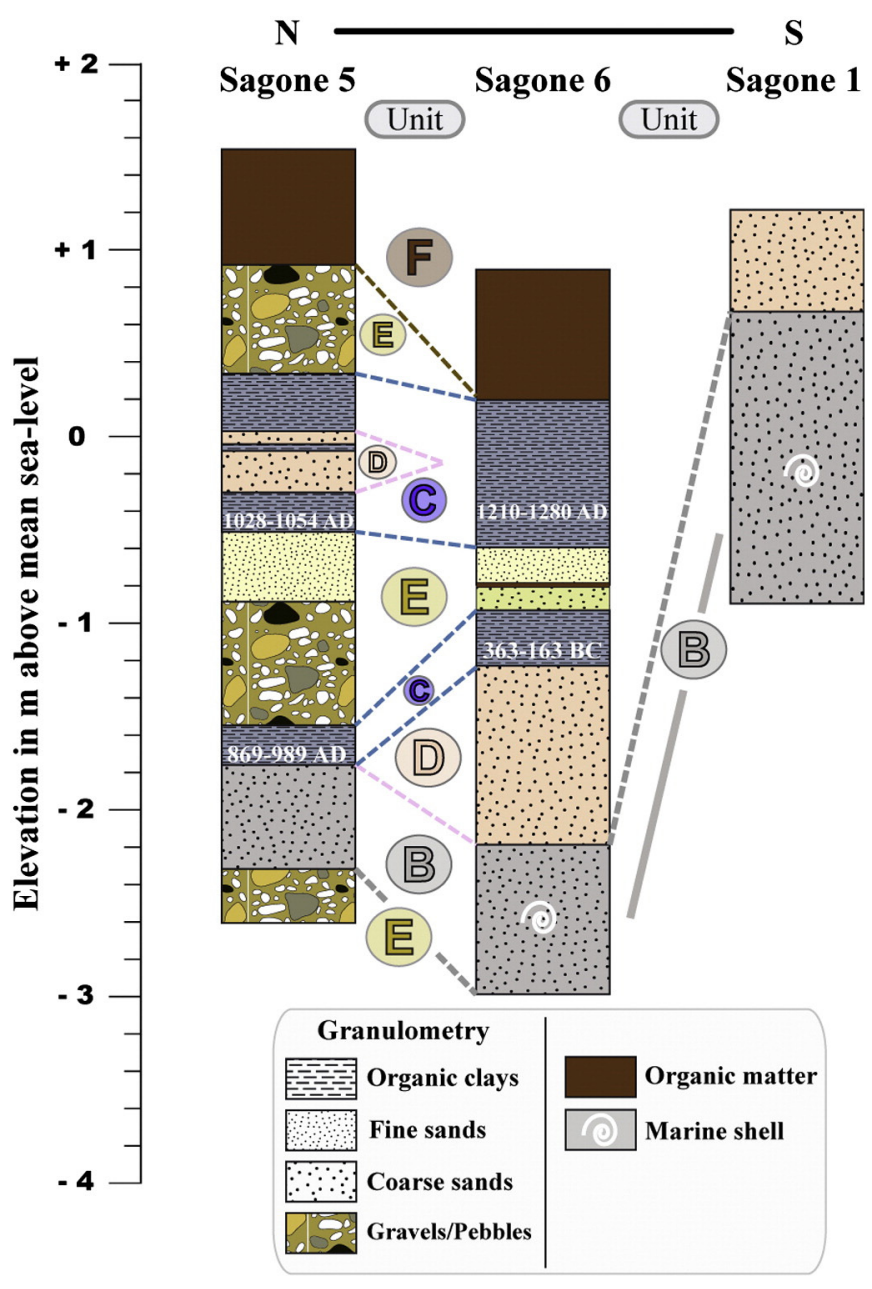

Fig. 8. Core profiles of Sagone 5, 6 and 1 boreholes.

Alnus glutinosa, Poaceae is much more strongly represented in these two upper samples (16\% and 25\%) than previously, while the percentages of herbaceous taxa, such as Cichorioideae, Asteroideae, Rumex-type and
Plantago lanceolata-type, decrease. Aquatic and hygrophilous taxa are still represented. There is no evidence of pollen from cultivated crops or of coprophilous fungal spores in these samples.

\subsection{Electrical resistivity tomography measurements}

ERT profile SAG01 (Fig. 10A), a W-E oriented section located in the westernmost part of the plain, was measured over a total length of $160 \mathrm{~m}$ (inter-electrode spacing $2.5 \mathrm{~m}$ ). The vertical resolution is about $20 \mathrm{~m}$ and core Sagone 9 is situated in the middle part of the profile, enabling us to relate the electrical signal to the granulometry. A first geoelectric unit (GE1, Fig. 10A), which is found between the surface and ca. $2.5 \mathrm{~m}$ below mean sea level (bmsl) exhibits generally intermediate resistivity values $(20-200 \Omega \cdot \mathrm{m})$. The stratigraphy of core Sagone 9 indicates the presence of marine coarse sands from ca. 1 to $3 \mathrm{~m}$ below sea level (from 2 to ca. $4 \mathrm{~m}$ below the surface). Superficial high resistivities $(>400 \Omega \cdot \mathrm{m})$ at the western edge (GE1a, Fig. 10A) are attributable to the granitic bedrock associated with coarse-grained material (footslope deposits). The easternmost part of the first geoelectric unit (GE1b, Fig. 10A) reveals an increase of the signal (locally $>200 \Omega \cdot \mathrm{m}$ ) in two horizontal layers: the first at the surface while the second is at ca. $3 \mathrm{~m}$ bmsl. The vicinity of the modern river course of the Sagone explains the increase in the resistivity signal due to the deposition of coarse fluvial material (flood events) and/or overbank deposits (fine sediments). The second geoelectric unit GE2, as in the two other ERT profiles (GEd on Fig. 10B), exhibits low values $(<20 \Omega \cdot \mathrm{m})$ in the lowermost part of the SAG01 section and is found from 4-5 bmsl. The third geoelectric unit/anomaly (Ge3, Fig. 10A) is at a depth of $12 \mathrm{~m}$ below the surface ( $10 \mathrm{~m}$ below present day sea level), just west of the midpoint of the SAG01 ERT profile.

The resistivity values are intermediate $(20-200 \Omega \cdot \mathrm{m})$ and could indicate the presence of a hard structure such as a bedrock outcrop or a paleosurface (Pleistocene alluvial terrace). Unfortunately, the coring equipment could not reach such a depth; further drilling may elucidate the relationship between granulometry and this resistive anomaly.

ERT profile SAG02 (Fig. 10B), a WNW-ESE oriented section located in the central part of the plain, was measured over a total length of $128 \mathrm{~m}$ (inter-electrode spacing $2 \mathrm{~m}$ ). Vertical resolution is about $15-16 \mathrm{~m}$ and core Sagone 5 is situated in the middle part of the profile, enabling us to relate the electrical signal to the granulometry. Four main geolectric units can be distinguished: The first geoelectric unit (GEa, Fig. 10B) is
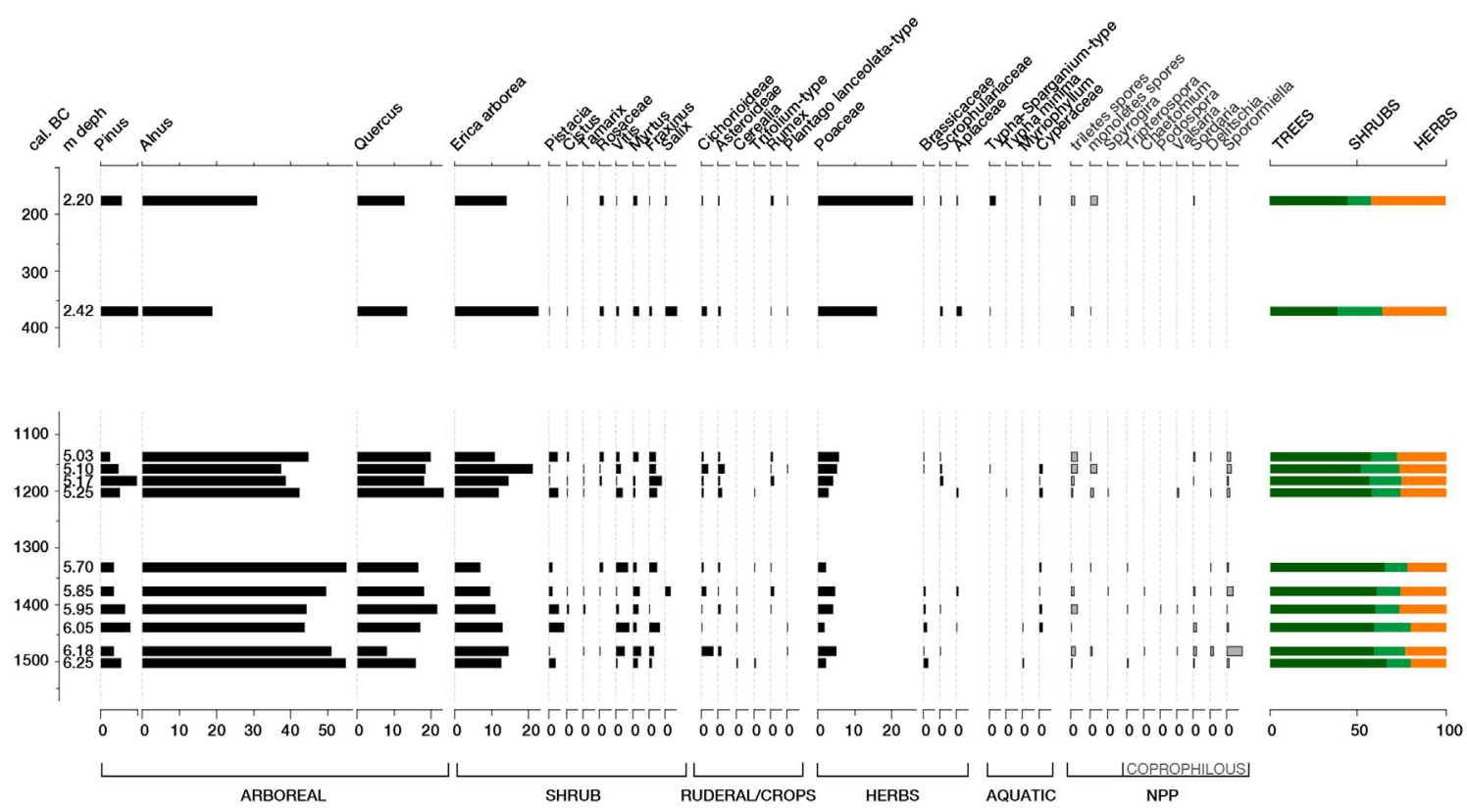

Fig. 9. Pollen diagram for core Sagone 7 (see Fig. 5 and Table 1 for location). 

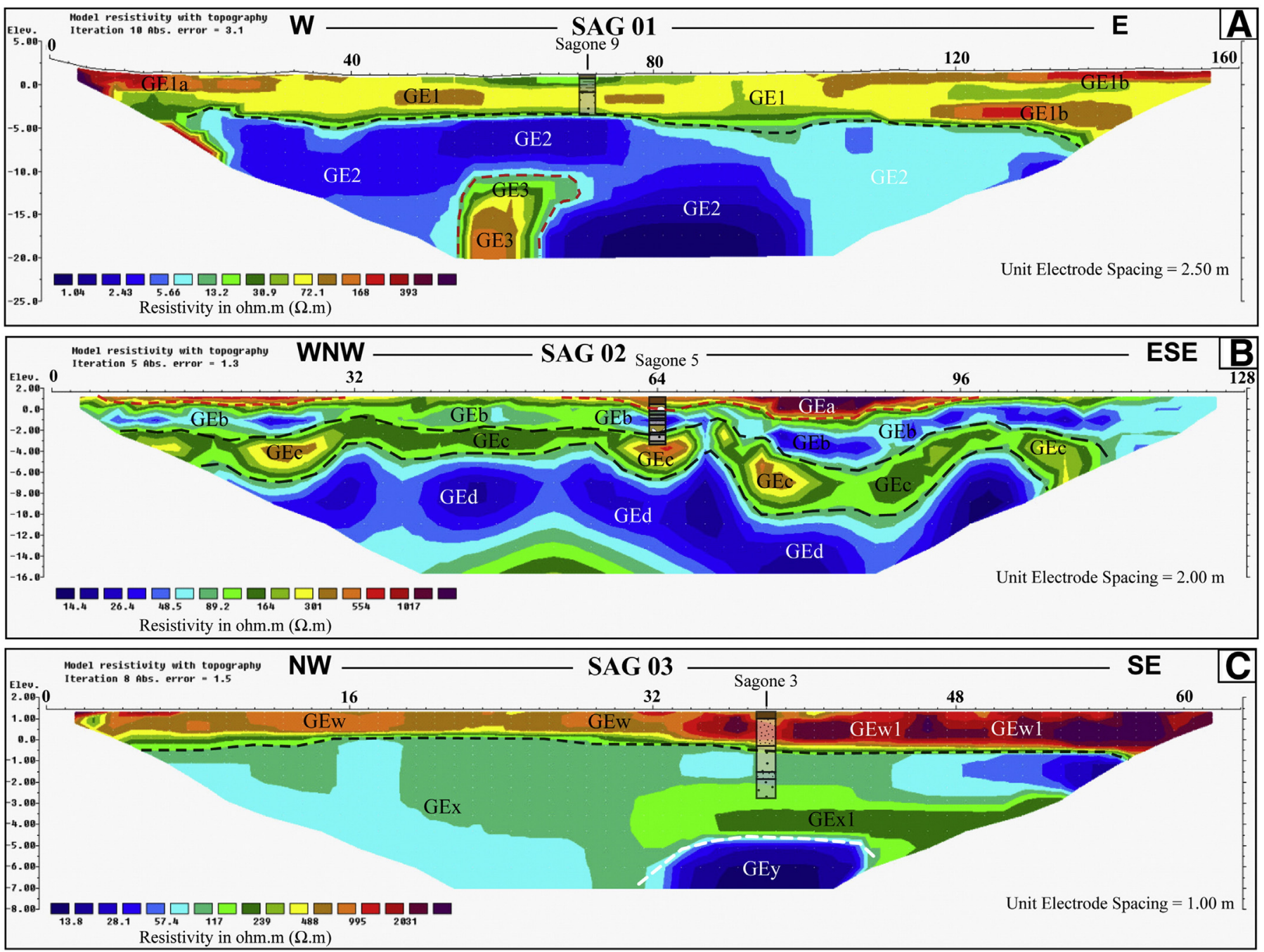

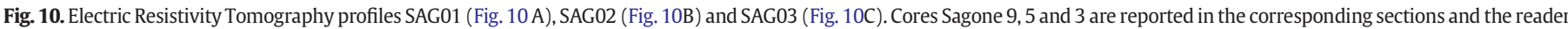
can refer to the description of the sedimentary units.

found between the surface and ca. $0.20 \mathrm{~m}$ above mean sea level; it has very high resistivity values, exceeding $1000 \Omega \cdot \mathrm{m}$. The granulometry derived from the Sagone 5 core reveals the presence of coarse dry sands and gravels 1-2 m below the surface. The second geoelectric unit (GEb, Fig. 10B) is encountered from $0.20 \mathrm{~m}$ above mean sea level to ca. $2 \mathrm{~m}$ below mean sea level, and exhibits low to intermediate resistivity values $(20-200 \Omega \cdot \mathrm{m})$. Sedimentological results from core Sagone 5 indicate the alternation of very fine material (gray stiff clays) with fine to medium sands. The third geoelectric unit (GEc, Fig. 10B) is situated from $2 \mathrm{~m}$ to ca. $8 \mathrm{~m}$ below mean sea level (Fig. $10 \mathrm{~B}$ ); the resistivity values are intermediate $(20-200 \Omega \cdot \mathrm{m})$ to high $(>200 \Omega \cdot \mathrm{m})$ with local very high values, exceeding $500 \Omega \cdot \mathrm{m}$ (in the mid-part of the profile). Grain-size analyses of the Sagone 5 core indicate the presence of two layers of fluvial material composed of gravels and pebbles (Fig. 8), at 2 to $3 \mathrm{~m}$ bmsl. These two coarse layers are well represented in the ERT profile SAG02 by high resistivity values $(>200 \Omega \cdot \mathrm{m})$. The irregular shape of the GEc geolectric unit can therefore be associated with a palaeochannel from electrodes 64 to 96, in the vicinity of core Sagone 5 core. The fourth geoelectric unit (GEd, Fig. 10B), situated from ca. 7 to $15-16 \mathrm{~m}$ deep, is characterized by uniformly low resistivity values $(<20 \Omega \cdot \mathrm{m})$. Although no granulometric information is available for this section, since the core sedimentary records do not exceed $6.3 \mathrm{~m}$ in depth, it is noteworthy that based both on the thickness and the resistivity values, GEd can be compared with GE2 from the SAG01 ERT profile (Fig. 10A).
ERT profile SAG03 (Fig. 10C), a NW-SE oriented section located in the westernmost part of the plain, was measured over a total length of $64 \mathrm{~m}$ (inter-electrode spacing $1 \mathrm{~m}$ ). Vertical resolution is about $8 \mathrm{~m}$ and core Sagone 3 is situated in the middle part of the profile. Several morpho-sedimentological units can be identified: the first is found between the surface (ca. $+1.5 \mathrm{~m}$ amsl) and ca. $2 \mathrm{~m}$ depth and exhibits high resistivity values $(\mathrm{R}>300 \Omega \cdot \mathrm{m}$ ) that increase suddenly (R values generally $>1000 \Omega \cdot \mathrm{m}$ ) from the mid part of the profile, in the vicinity of core Sagone 3 core. The borehole stratigraphy reveals the deposition of coarse dry sands (pink in colour) that form the modern sand dune ridges in this area. Therefore, the high resistivity values recorded in the southeasternmost part of the profile are indicative of compacted dry coarse sands. The second geoelectric unit from SAG01 (GEx, Fig. 10C) is found from ca. 0.5 to $6-7 \mathrm{~m}$ below bmsl (from ca. 2 to $8 \mathrm{~m}$ below the surface) and contrasts sharply with the previous unit; the resistivity values generally range from 20 to $200 \Omega \cdot \mathrm{m}$, similar to GEc from the SAG02 ERT profiles (Fig. $10 \mathrm{~B}$ ). In the NW part of the profile, there is no significant variation of the signal; while in the SE part of the section there are locally very low values $(<20 \Omega \cdot \mathrm{m})$ that are found above and below a more resistive layer (GEx1, from ca. 100 to $250 \Omega \cdot \mathrm{m}$, Fig. 10C). Correlation with the borehole Sagone 3 stratigraphy indicates the presence of gray marine sands and the aquifer. Hence, the strong contrast in resistivity values cannot be directly related to the presence of hard/soft material in the sub-soil, since the Sagone 3 borehole stratigraphy situated in the mid-point of the SAG01 profile reveals the 
deposition of homogenous material. One possible explanation for this important contrast could be the presence of the aquifer, at the transition from the marine sands and the sand dune deposits, which could locally modify the conductivity/resistivity signals. A final unit (GEy, Fig. 10C) is potentially identified in the lower most part of the profile, from $5 \mathrm{~m}$ bmsl and exhibits very low values $(<20 \Omega \cdot \mathrm{m})$, similar to GE2 from SAG01 (Fig. 10A) and GEd from SAG02 (Fig.10B). However, there is no granulometric information available for this deep part of the section and no interpretation can therefore be made in relation to the sedimentology.

\section{Discussion}

5.1. Recent Holocene palaeogeographic evolution of the Sagone coastal plain and implications for local human occupation

Sedimentological data and radiocarbon dating results derived from the 9 boreholes drilled in the Lower Sagone River enable the reconstruction of the shoreline and the hydrographical changes since the Bronze Age. During the Bronze Age, the landscape configuration was characterized by the existence of a large freshwater pond on the right bank of the Sagone River, from at least the first half of the second millennium BC to the 12th/11th Century BC (Fig. 11). The origin of this freshwater pond could be explained by the presence of a palaeorelief (granitic outcrop or Pleistocene marine terrace?), revealed by the ERT measurements of the SAG01 profile (Fig. 10A), which is isolated from the sea water derived from the Sagone River. Today, alluvial deposits have created a large fertile plain where ponds or swamps are completely absent. The combination of sedimentological data derived from the boreholes drilled for the present study and from the BRGM deep boreholes (Fig. 2) highlights the large extent of this former freshwater pond: it probably extended along a N/S axis and measured ca. $1 \mathrm{~km}$ long and ca. $500 \mathrm{~m}$ wide. Archaeological records during this period are mainly confined to the right bank of the river and are only linked to the presence of several figural menhirs, and no other structures (such as houses) have been identified in the area. Their location, to the western and northern margins of this palaeo- freshwater pond, might relate to this landscape feature; other studies (Istria and Harnéquaux, 2010) have suggested that these megaliths may have served to mark important landscape features. Since few palaeoenvironmental studies based on sediment cores have been conducted in Corsica in the proximity of Menhir statues this hypothesis cannot be evaluated more generally but perennial fresh water would have been an unusual and valuable feature in the semi/seasonally-arid Corsican landscape. Such water sources could have provided many natural resources in addition to fresh water, such as mud and reeds that could be used for making pottery and building houses, as well as for attracting wild game. During the second half of the second millennium $\mathrm{BC}$, it is also noteworthy that the palaeo-shoreline was located $300 \mathrm{~m}$ north of its present day position, where boreholes Sagone 2 and 3 are situated. Unfortunately, the palaeo Sagone
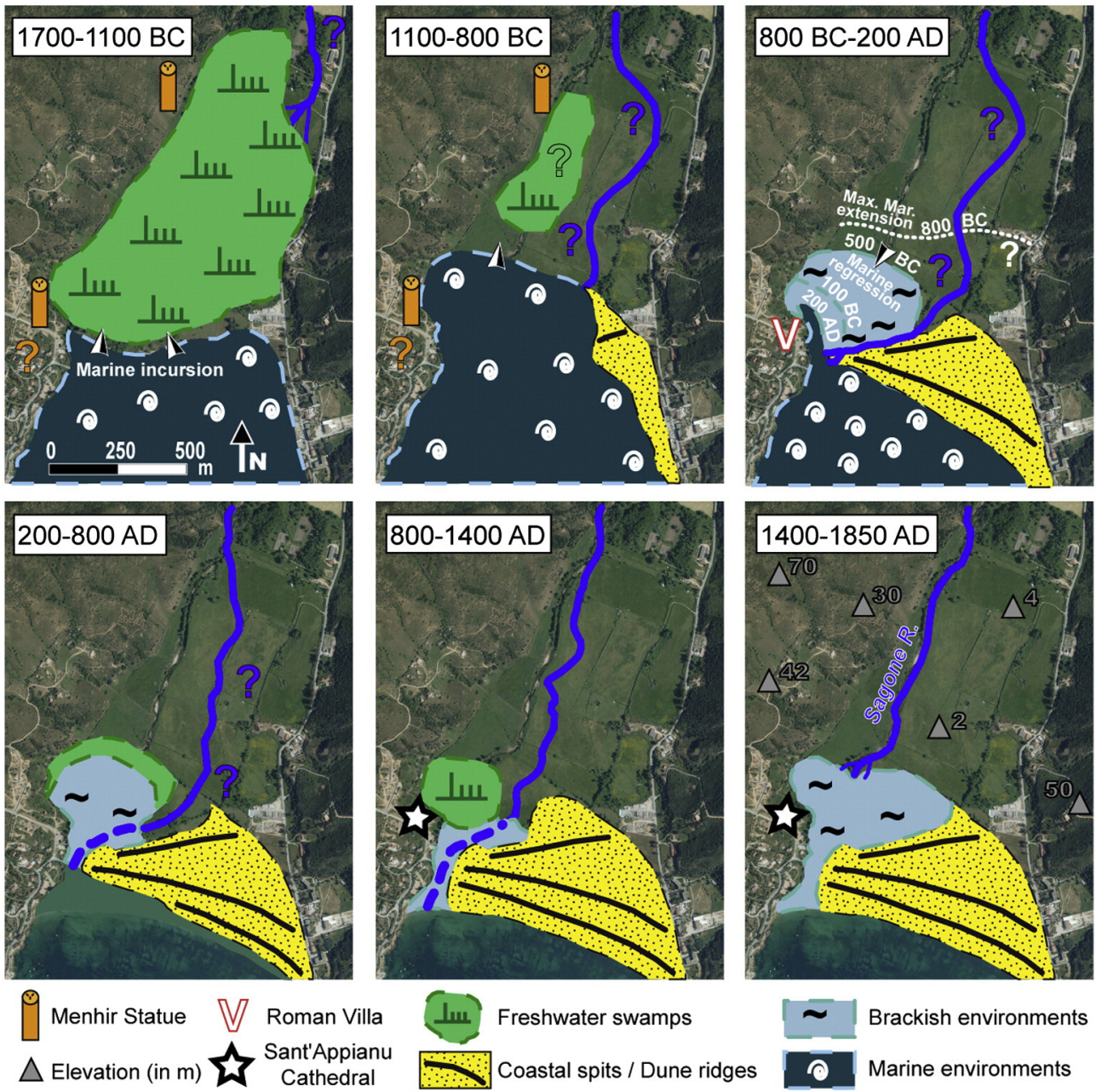

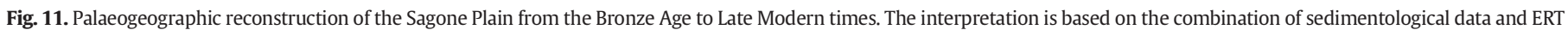
measurements obtained for the present study, together with the 1970s boreholes drilled for geotechnical purposes (see Fig. 2). 
river course is difficult to locate accurately since there is no fluvial deposition recorded in the various boreholes during the Late Bronze Age. However, the existence of a palaeo- freshwater pond in the westernmost part of the plain and the presence of coarse marine sediments (reworked granites) probably indicate that the Sagone River was flowing in the northeastern most part of the valley, where the modern city of Sagone is located.

Subsequently, during the Late Bronze Age, at ca. 1100/1000 cal. BC, a marine incursion occurred and flooded the freshwater pond (Fig. 11). Recent work indicates that the sea-level position was $-1.5 \mathrm{~m} \pm$ $0.4 \mathrm{~m}$ lower than today during the 2 nd millennium BC (Vacchi et al., 2016). This followed several episodes of probable extreme surges, possibly related to exceptional storms that invaded the ponds from ca. 1300-1100 cal. BC. Similar extreme events, related to an increase in storm activity during cold climatic events (RCC), have also been observed in the NW Mediterranean Sea during the 1600-1100 cal. BC period (Sabatier et al., 2012) and in particular along the southwest coast of France (Sabatier, 2012). Later, a full marine environment (open marine bay) prevailed from ca. $1100 / 1000$ cal. BC to the 8th Century BC in the Sagone coastal plain. In parallel, a gradual shifting to the west of the Sagone estuary allowed the formation of several coastal spits/barriers that were transformed into sand dunes ridges following a ENE-WSW direction.

From the 8th Century BC to the 2nd Century AD (Fig. 11), the large marine bay gradually changed into an open lagoon (separated from the sea by a series of coastal barriers) and finally the deltaic progradation of the Sagone river resulted in the siltation of the cove following a NE/SW direction around the 2nd to the 3rd Century AD. At that time, the sea-level position was $-0.8 \mathrm{~m} \pm 0.4 \mathrm{~m}$ (Vacchi et al., 2016). During the Roman period, there was only a narrow access from the sea to the area of the Roman settlement (located where the Sant'Appianu Cathedral was later built), matching the present-day position of the estuary. The sedimentological results clearly reveal that there was no large open marine bay during the Late Iron Age and Roman period at the foot of the rocky promontory. In contrast, the landscape configuration from the 2 nd Cent. BC to the 1 st Cent. AD was characterized by the presence of a very confined lagoon below the Roman site and a very narrow access to sea still existed, possibly due to human actions. Archaeological investigations conducted near estuaries along the southwestern coast of Corsica have produced evidence for importation of goods (e.g., olive oil, ceramics, fish sauce) mainly from Northern Africa (what is now Algeria and Tunisia; Istria et al., 2011). The goods were subsequently distributed throughout Corsica from natural harbours (in the absence of constructed harbours, such natural harbours were particularly significant) located in the lower river valleys of Corsica. Sagone was apparently chosen as such a coastal "harbor" due to its naturally protected marine bay. Archaeologists have clearly highlighted that there was a maritime route starting from Sardinia and running along the entire west coast of Corsica (Arnaud, 2005), connecting several coastal sites located in estuaries such as Sagone.

During the 10th to the 12th Century AD (the period in which the Sant'Appianu cathedral was built), the Sagone River flowed in the central part of the coastal plain (Fig. 11), approximately where core Sagone 5 was located. During this period, a brackish pond still existed at the foot of the promontory where the cathedral was built, while the shoreline was located approximately at its present day position. Finally, during the Little Ice Age (1400-1850 cal. AD; Fig. 11), large brackish swamps covered all of the modern coastal plain while the river mouth was probably located further north than today (Fig. 11), on the central northern margin of the swamps. Low energy deposition is confirmed by the very fine material (clays) recorded for this period in almost all of the cores drilled in the central and eastern parts of the plain. An increase of precipitation at this time is well-documented across the Mediterranean (Pichard, 1995 and 2014; Grove, 1988) and increases in river flow would have contributed to regular flooding of the estuaries and coastal plains.

\subsection{Evolution of vegetation in the Sagone Valley during the bronze age and} late iron age

The palynological analysis of one of the cores retrieved in the Sagone Valley provides the first evidence of the vegetation of the Western coast of Corsica during Bronze Age, from ca. 1500 to 1100 cal. BC (at high chronological resolution), and during the Late Iron Age, around the 4th to the 2nd Century cal. BC (at lower chronological resolution).

Between 1500 and $1100 \mathrm{cal}$. BC, the vegetation of the Sagone area was characterized by a mixed forest of oak and Erica arborea. Thermophilous shrub communities of Pistacia, Vitis, Myrtus and mesophilous Fraxinus were present at this time. The abundance of Alnus glutinosa pollen in the sedimentary record reflects the existence of an alder community at a local scale. Considering the data supplied by the sedimentary analyses, which indicates the existence of a freshwater lake/pond at this time, it is likely that Alnus glutinosa grew and developed as a riverine community favored by this wet environment. The existence of the freshwater pond is further attested by the occurrence of several aquatic plants such as Typha and/or Sparganium (as indicated by the TyphaSparganium pollen type), Myriophyllum, and Spirogyra algae. Hygrophilous Cyperaceae communities were also present in Sagone, corroborating the existence of a fresh water-body in Sagone despite the proximity of the sea.

While Alnus glutinosa provides a local signal, it is possible that Pinus is overrepresented in the pollen diagram. Considering the well-known ability of pines to produce and disperse pollen, it is likely that the low percentages indicate that pinewoods were absent from the immediate area and their presence in the record is rather explained by the medium to long-distance transport of pollen from higher altitudes away from the coast. The vegetation of the Sagone Valley at this time corroborates some of the hypotheses proposed by M. Reille (1984 and 1992), specifically those regarding the spread of Quercus ilex in Western Corsica during the Subboreal period and mainly after 2300 BCE. This phenomenon is also observed in the Western Mediterranean (Jalut et al., 2000 and 2009). The data from Sagone demonstrate that the spread of evergreen oak in a forest exclusively occupied by Erica and Arbutus had already occurred prior to the 2nd millennium cal BC. However, although M. Reille considered this change to be human-induced in Corsica, the evidence of human activities in the pollen record from the Sagone Valley is rather limited at this time. The modest evidence of ruderal and nitrophilous plants such as Cichorioideae, Rumex, and Plantago lanceolata in the pollen record indicates that some human activity could have occurred at that time in Sagone, although the low percentages of these taxa suggest that such activity was not widespread. Minor agricultural activity is reported at least during the 15th century cal BC. Considering that Cerealia pollen is very poorly dispersed (Diot, 1999), such that it may be underrepresented in the pollen record, the minor extent of agriculture could also be explained as a result of the swampy substrate and high humidity environment linked to the pond and the wetland surroundings, which did not provide optimal conditions for cereal cultivation at a local scale. The occurrence of coprophilous fungal spores indicates the presence of herbivorous mammals. The coeval human activity reported in the pollen record would support the occurrence of grazing activity in the area of Sagone around the half 2nd millennium cal BC. This feature could suggest the practice of a mixed farming economy based on animal husbandry and some cultivation. During the 12th century cal BC, which probably corresponds to the maximal extent of the identified freshwater lake (see above), a decrease in Alnus glutinosa pollen is witnessed, indicating that the extent of the local alder forest declined. The sedimentary analysis indicates that the pond was shrinking in the Late 2nd millennium BC. As a result, less humid conditions occurred and subsequent development of Alnus glutinosa was likely constrained. At this time Erica and mixed oak forest increase slightly in the pollen record. Whether or not this percentage variation reflects the spread of those communities is difficult to assess. However, we consider that the decline in Alnus glutinosa forest could have resulted in the improved pollen 
representation of Erica and Quercus, even if these communities remained unchanged. The existence of anthropogenic and ruderal plants at this time together with the persistence of grazing activity, as suggested by the presence of Sporormiella, indicates that humans were still present around Sagone ca the 12th century cal. BC. The lack of cereal pollen during this same period should be interpreted with caution, as the available pollen record provides only a very local signal of cereal abundance. Even if the specific details of human occupation remain poorly attested from the palynological record, it is clear from the relative stability of the pollen data that Bronze Age society did not cause major changes in the vegetation of the Sagone Valley during the late 2nd millennium cal. BC. Due to the marine incursion, the pollen record of core Sagone 7 does not record the evolution of vegetation during the first half of the 1st millennium cal. BC. In spite of this hiatus, two samples from the 4th and 2nd centuries cal. BC indicate that the landscape at that time already differed from that of the Bronze Age period. The main changes occurred in the Alnus glutinosa forest, which seems to have retreated by this time. Grasslands, as indicated by the spread of Poaceae, could have occupied the habitat where alder grew previously, indicating the development of a more open landscape within the general context of alluvial plain formation by the Sagone River. Unfortunately, due to the lack of pollen data prior to the 4th century cal. BC, we can only note the occurrence of this change, and not follow its evolution. Nevertheless, sedimentary data, derived from cores Sagone 5, 7, 8 and 9 drilled in the Central West part of the plain (see above), suggest that the progradation of the Sagone delta was indeed occurring during the last centuries cal. BC. A likely hypothesis is that the landscape shifted from a freshwater pond environment surrounded by alder to a delta where riparian vegetation species were progressively excluded and replaced by grasslands, except immediately surrounding the channel. The pollen record linked to the Late Iron Age does not indicate a strong human impact prior to the Roman occupation in the area. The occurrence of pollen from ruderal and anthropogenic taxa suggests that humans were still occupying the area of Sagone, but no major signs of farming activity are recorded, except for the evidence of the coprophilous Sordaria spores at $2.20 \mathrm{~m}$ depth. However, this evidence should be interpreted as reflecting the presence of herbivorous animals, rather than as substantive proof of pastoral activity. The limited spatial representativeness of the pollen data, however, makes inference from negative evidence difficult, and sampling on a larger spatial scale may alter these conclusions.

\section{Conclusion}

Coring evidence, and sedimentological, geophysical (2D geometry of the sediment bodies), geomorphological and palynological studies enable for the first time a palaeogeographic reconstruction of the Sagone coastal plain over the last four millennia. Moreover, the present study is the first attempt in Corsica to reconstruct Mid- to Recent Holocene palaeoenvironmental evolution of a deltaic plain based on coring results and ${ }^{14} \mathrm{C}$-dated chronostratigraphy. This paper also examines the reciprocal relationships of the rapidly changing landscape with human occupation since the Bronze Age. The sediment cores reveal a different landscape configuration during the Bronze Age (and probably also in earlier times) compared to today, with the disappearance by the $1 \mathrm{st}$ millennium BC of the large freshwater pond of ca. $1-2 \mathrm{~km}^{2}$ area that had previously dominated the northeastern part of the lower valley while the Sagone River mouth was located ca. 1.5-2 km further north. During Iron Age and Roman times, deltaic progradation forced the Sagone River mouth to shift southwestwards, following the formation of the dunes ridges with a NE/SW orientation. The results reveal that during Roman times (from the 1st Cent. BC to the 2nd Cent. AD), a protected bay existed at the foot of the Sant'Appianu promontory providing an anchorage for boats. In addition to the palaeogeographic reconstruction of the lower Sagone Valley, for the first time the vegetation history of the lower valley during the Bronze Age has been reconstructed (this area was not studied by M. Reille), suggesting that the vegetation was little affected by anthropogenic deforestation in the catchment (semi-open forest consisting of riverine trees such as alder and shrub where Erica arborea was the main taxa). In addition, it can also be proposed that the dynamics of such a riparian environment were mainly triggered by changes in water balance while human pressure remained relatively low. From an archaeological perspective, no permanent settlements are evident until the Mid-1st millennium AD. Prior to that date there are some indications of possible occupation during the Bronze Age (presence of figural statues dated from Late Bronze Age, e.g. 1200-1000 cal. BC) but there are Iron Age remains. Pastoralism as a primary subsistence activity is recorded during the Bronze Age while it is little recognized during the Late Iron Age in the Sagone catchment. Cereal cultivation was probably limited during both periods due to the existence of a large freshwater pond $\left(1-2 \mathrm{~km}^{2}\right)$, that was transformed into brackish swamps in the entire lower river valley during the 1st millennium BC; and the local people may have been confined to cultivating the gentle slopes of the surrounding hills. Future coring in the east central part of the plain may provide a more complete view both of the Holocene vegetation evolution and the sedimentary dynamics.

\section{Acknowledgements}

This article is a contribution of the multidisciplinary research programme Géoarchéologie des basses vallées fluviales: la nécessaire prise en compte de l'évolution paysagère au cours de l'Holocène (Programme Collectif de Recherche, 2013-2015) directed by Matthieu Ghilardi (CEREGE) and funded by the French Ministry of Culture and Communication (Direction Régionale des Affaires Culturelles de Corse, Ajaccio). It aims to reconstruct the relationships between landscape evolution and the human occupation of the lower river valleys of Corsica. We are grateful to Franck Leandri, Director of Archaeology in Corsica, for his constant support and for the authorizations delivered for conducting the coring campaigns in May and September 2013. Financial support was also provided by the MISTRALS/PALEOMEX national research programme from CNRS (INEE-INSU) and directed for the Archeomed workshop by Laurent Carozza and Laurent Lespez. Labex OT-Med (AixMarseille University) is also thanked for developing multidisciplinary research in Corsica. Finally, Luc Beaufort (CEREGE), Julien and Maddie Marcaggi, and Joseph Ghilardi are acknowledged for their invaluable help.

\section{References}

Andersen, S.-T., 1979. Identification of wild grass and cereal pollen, Danmarks Geologiske Undersøgelse, árbog 1978. pp. 69-92.

Anthony, E., Marriner, N., Morhange, C., 2014. Human influence and the changing geomorphology of Mediterranean deltas and coasts over the last 6000 years: from progradation to destruction phase ? Earth Sci. Rev. 139, 336-361.

Arnaud, P., 2005. Les Routes de La Navigation Antique: itinéraires en Méditerranée Paris. Beauvais, A., Ritz, M., Parisot, J.-C., Bantsimba, C., Dukhan, M., 2004. Combined ERT and GPR methods for investigating two stepped lateritic weathering systems. Geoderma 119, 121-132.

Beauvais, A., Parisot, J.-C., Savin, C., 2007. Utramafic rock weathering and slope erosion processes in a south West Pacific tropical environment. Geomorphology 83 (1-2), $1-13$

BRGM, 2012. BSS Banque de données du sous-sol BRGM. http://infoterre.brgm.fr.

Butzer, K.W., 2005. Environmental history in the Mediterranean world: cross-disciplinary investigation of cause-and-effect for degradation and soil erosion. J. Archaeol. Sci. 32 (12), 1773-1800.

Cesari, J., Istria, D., Leandri, F., 2016. Nouvelles découvertes de statues-menhirs du groupe de Sagone à Sant'Appianu (Vico, Corse-du-sud). 5. Patrimoine d'une île (in press).

Cesari, J., Leandri, F., 1994. La statue-menhir d'U Scumunicatu (Cargèse, Corse-du-Sud) et le groupe des statues-menhirs de Sagone. Préhistoire Anthropologie Méditerranéennes 3. université de Provence, Aix-en-Provence, pp. 151-161.

Cesari, J., Leandri, F., 2007. Recherches récentes sur la statuaire mégalithique corse. In: D'Anna, A., Cesari, J., Ogel, L., Vaquer, J. (Eds.), Corse et Sardaigne préhistoriques relations et échanges dans le contexte méditerranéen, 128e Congrès national des sociétés historiques et scientifiques, Bastia, 2003. CTHS, Paris, pp. 199-209. 
Clauzon, G., 1975. Preuves et implications de la régression endoréique messinienne au niveau des plaines abyssales: l'exemple du Midi méditerranéen français. Bulletin de l'Association des Géographes français 52 (429), 317-333.

Conchon, O., 1999. Le littoral de Corse (France) au Quaternaire. Quaternaire 10, 95-105.

Courtaud, P., Cesari, J., Leandri, F., Nebbia, P., Perrin, T., Hansen, H.C., Zemour, A., 2014. La sépulture mésolithique de Campu Stefanu (Sollacaro, Corse-du-sud, France). In: Sénépart, I., Léandri, F., Cauliez, J., Perrin, T., Thirault, E. (Eds.), Chronologie de la Préhistoire récente dans le sud de la France, Actualités de la RechercheActes du colloque $10^{\mathrm{e}}$ Rencontres Méridionales de Préhistoire Récente (Porticcio, 18-20 Octobre 2012). Archives d'Ecologie Préhistorique, Toulouse, pp. 275-287.

Diot, M. F. 1999. "Pollen analysis of wild and domestic wheats under experimental cultivation», en: Anderson, P.C. (ed.), Prehistory of Agriculture. New Experimental and Ethnographic Approaches. Los Angeles: Cotsen Institute of Archaeology at UCLA. pp.: 66-69.

Fægri, K., Iversen, J., 1989. In: Faegri, K., Kaland, P.E., Krzywinski, K. (Eds.), Textbook of Pollen Analysis, 4a ed. The Blackburn Press, New Jersey (328 p).

Gamisans J., 1999. La végétation de la Corse. (Ed. Édisud), 391 p.

Ghilardi, M., Psomiadis, D., Pavlopoulos, K., Müller-Celka, S., Fachard, S., Theurillat, T., Verdan, S., Knodell, A., Theodoropoulou, T., Bicket, A., Bonneau, A., DelangheSabatier, D., 2014. Mid- to Late Holocene shoreline reconstruction and human occupation in Ancient Eretria (South Central Euboea, Greece). Geomorphology 208, 225-237. http://dx.doi.org/10.1016/j.geomorph.2013.12.006.

Ghilardi, M., Sanderson, D., Kinnaird, T., Bicket, A., Balossino, S., Parisot, J.-C., Hermitte, D. Guibal, F., Fleury, J., 2015. Dating the bridge at Avignon (South France) and reconstructing the Rhone River fluvial palaeo-landscape in Provence from medieval to modern times. Journal of Archaeological Science: Reports 4, 336-354. http://dx. doi.org/10.1016/j.jasrep.2015.10.002.

Griffiths, D.H., Turnbull, J., Olayinka, A.I., 1990. Two-dimensional resistivity mapping with a computer-controlled array. First Break 8, 121-129.

Grosjean, R., 1961. Filitosa et son contexte archéologique. Monuments et mémoires de la fondation Eugène Piot 52 (1), 3-96.

Grove J.M., 1988. The Little Ice Age. Methuen, London, 498 p.

Istria, D., Harnéquaux, M., 2010. Sevi-Sorru-Cruzzini-Cinarci [Découvrir le patrimoine bâti]. CRDP de Corse, Ajaccio.

Istria, D., Françoise, J., Pellegrino, E., 2012. Les deux baptistères du groupe épiscopal de Sagone (Corse-du-Sud). Galvanotechnik 69-2, 195-208.

Istria D., Martorelli R., Pergola P., Vismara C., 2011. Sardinien und Korsika in römischer zeit, éditions Ph. von Zabern, Darmstadt, $161 \mathrm{p}$.

Istria, D., 2009. La cathédrale Sant'Appianu de Sagone. Proposition de relecture architecturale des églises paléochrétiennes, médiévales et modernes. Archéologie Médiévale 39, 25-39.

Istria D., 2014a. Corse médiévale. Guides archéologiques de la France, Edition du Patrimoine Centre des monuments nationaux, $128 \mathrm{p}$.

Istria, D., 2014b. Sant'Appianu de Sagone. In: Michel, F., Pasqualaggi, D. (Eds.), La Corse 2A-2B. Carte archéologique de la Gaule, Paris, pp. 136-141.

Jalut, G., Dedoubat, J.J., Fontugne, M., Otto, T., 2009. Holocene circum-Mediterranean vegetation changes: climate forcing and human impact. Quat. Int. 200, 4-18.

Jalut, G., Esteban-Amat, A., Bonnet, L., Gauqueli, T., Fontugne, M., 2000. Holocene climatic changes in the Western Mediterranean, from south-east France to south-east Spain. Palaeogeogr. Palaeoclimatol. Palaeoecol. 160, 255-290.

Leandri F., Istria D., 2015. Corse. Richesses archéologiques de la Préhistoire à l'époque moderne. Dossiers d'archéologie, 370, 83 p.

Loke M.H., 2003. RES2DINV, Rapid 2-D Resistivity and IP Inversion Using the Least-Square Method. Geotomo Software user's manual, Singapore, 123 p.

Mérimée P., 1840. Notes d'un voyage en Corse, Paris, 256 p.

Pêche-Quilichini, K., 2014. U Castellu. In: Michel, F., Pasqualaggi, D. (Eds.), La Corse 2A-2B. Carte archéologique de la Gaule, Paris, pp. 103-104

Pichard, G., 2014. Pluies et crues en bas Rhône et caractérisation du Petit Âge de Glace (PAG). Méditerranée 122, 31-42.

Pichard, G., 1995. Les crues sur le bas Rhône de 1500 à nos jours. Pour une histoire hydroclimatique. Méditerranée 82, 105-116.

Quesnel, Y., Jrad, A., Mocci, F., Gattacceca, J., Mathé, P.-E., Parisot, J.-C., Hermitte, D., Dumas, V., Dussouillez, P., 2011. Geophysical signatures of a roman and early medieval necropolis. Archaeol. Prospect. 18, 105-115.

Reille, M., 1984. Origine de la végétation actuelle de la Corse sud-orientale; analyse pollinique de cinq marais côtiers. Pollen Spores 26, 43-60.
Reille, M., 1992. Pollen et Spores d'Europe et d'Afrique Du Nord. Laboratoire de Botanique historique et Palynologie, Université d'Aix-Marseille III, Marseille.

Reille, M., 1995. Pollen et spores d'Europe et d'Afrique du nord. Supplément 1. Marseille: Laboratoire de Botanique historique et Palynologie. Université d'Aix-Marseille III.

Reille, M., 1998a. Pollen et spores d'Europe et d'Afrique du nord. Supplément 2. Marseille: Laboratoire de Botanique historique et Palynologie. Université d'Aix-Marseille III.

Reimer, P.J., McCormac, F.G., 2002. Marine radiocarbon reservoir corrections for the Mediterranean and Aegean seas. Radiocarbon 44, 159-166.

Reimer, P.J., Bard, E., Bayliss, A., Beck, J.W., Blackwell, P.G., Bronk Ramsey, C., Buck, C.E., Cheng, H., Edwards, R.L., Friedrich, M., Grootes, P.M., Guilderson, T.P., Haflidason, H., Hajdas, I., Hatte, C., Heaton, T.J., Hogg, A.G., Hughen, K.A., Kaiser, K.F., Kromer, B., Manning, S.W., Niu, M., Reimer, R.W., Richards, D.A., Scott, E.M., Southon, J.R., Turney, C.S.M., van der Plicht, J., 2013. IntCal13 and MARINE13 radiocarbon age calibration curves 0-50000 years cal BP. Radiocarbon 55 (4). http://dx.doi.org/10.2458/ azu_js_rc.55.16947.

Ritz, M., Parisot, J.C., Diouf, S., Beauvais, A., Diome, F., Niang, M., 1999. Electrical imaging of lateritic weathering mantles over granitic and metamorphic basement of eastern Senegal, West Africa. J. Appl. Geophys. 41, 335-344.

Rossi, P., Marre, J., 2010. Carte géologique France (1/50000), feuille Vicu-Carghjese (1113). Orléans: BRGM. Notice explicative par Rossi Ph., Mare J., Cocherie A., Caballero Y. (2010) (156 p).

Sabatier, P., 2012. Increased storm activity during Holocene cold events in the NW Mediterranean Sea. Abstract book, INQUA, Bern Switzerland (21-27th July 2011). Quaternary International, pp. 279-280, 420.

Sabatier, P., Dézileau, L., Colin, C., Briqueu, L., Bouchette, F., Martinez, P., Siani, G., Raynal, O., Von Grafenstein, U., 2012. 7000 years of paleostorm activity in the NW Mediterranean Sea in response to Holocene climate events. Quat. Res. 77, 1-11.

Siani G., Paterne M., Arnold M., Bard E., Métivier B., Tisnerat N., Bassinot F., 2000. Radiocarbon reservoir ages in the Mediterranean Sea and Black Sea, Radiocarbon, $n^{\circ} 42$, 271-280.

Siart, C., Hecht, S., Holzhauer, I., Altherr, R., Meyer, H.P., Schukraft, G., Eitel, B., Bubenzer O., Panagiotopoulos, D., 2010. Karst depressions as geoarchaeological archives: the palaeoenvironmental reconstruction of Zominthos (Central Crete) based on geophysical prospection, mineralogical investigations and GIS. Quat. Int. 216, 75-92.

Vacchi, M., Marriner, N., Morhange, C., Spada, G., Fontana, A., Rovere, A., 2016. Multiproxy assessment of Holocene Sea-level variability and improvements in the definition of the isostatic signal. Earth Sci. Rev. 155, 172-197.

Van Dam, R.L., 2012. Landform characterization using geophysics-recent advances, applications, and emerging tools. Geomorphology 137 (1), 57-73.

Van Geel, B. 2001. «Non pollen palynomorphs», en: J.P. Smol, H.J.B. Birks, W.M. Last (eds.) Tracking Environmental Change Using Lake Sediments. Vol. 3, Terrestrial, Algal and Silicaceaous Indicators. Dordrecht: Kluwer Academic Publishers. pp.: 99-119.

Vella, M.A., 2010. Approches géomorphologiques et géophysiques des interactions sociétés/milieux en Corse au cours de l'Holocène. 2 vol. Phd Thesis, University of Corsica, p. 314.

Vella, M.A., Ghilardi, M., Cesari, J., Léandri, F., Pêche-Quilichini, K., Demory, F., DelangheSabatier, D., Ottaviani Spella, M.M., Tabbagh, A., 2014. Evolution morphosédimentaire des marais de Canniccia à l'Holocène récent: implications paléoenvironnementales pour l'occupation du site d'I Calanchi/Sapar'Alta entre le Néolithique final et l'âge du Bronze final. In: Sénépart, I., Léandri, F., Cauliez, J., Perrin, T., Thirault, E. (Eds.), Chronologie de la Préhistoire récente dans le sud de la France, Actualités de la Recherche. Actes du colloque $10^{\mathrm{e}}$ Rencontres Méridionales de Préhistoire Récente (Porticcio, 18-20 Octobre 2012), Archives d'Ecologie Préhistorique, Toulouse, pp. 351-360.

Vella, M.A., Ghilardi, M., Diouf, O., Parisot, J.C., Hermitte, D., Provansal, M., Fleury, J., Dussouillez, P., Sabatier-Delanghe, D., Demory, F., Hartmann-Virnich, A., Delpey, Y., Berthelot, M., Bicket, A., 2013. Géoarchéologie du Rhône dans le secteur du pont Saint-Bénézet (Avignon, Provence, France) au cours de la seconde moitié du deuxième millénaire apr. J.-C.: approche croisée de géographie historique et d'étude paléoenvironnementale. Géomorphologie, Relief, Processus et Environnement 3, 287-310.

Vött A, 2007. Relative sea level changes and regional tectonic evolution of seven coastal areas in NW Greece since the mid-Holocene. Quaternary Science Reviews $n^{\circ} 26(7)$, 894-919.

Weiss, M.-C., 1984. Monte Lazzu: un site préhistorique et protohistorique de la Corse occidentale, BAR International Series 222 Oxford. 